\title{
Entrevista de Lia Zanotta Machado
}

\author{
Lia Zanotta Machado ${ }^{1}$ \\ Debora Regina Pastana ${ }^{2}$ \\ Márcio Ferreira de Souza ${ }^{3}$
}

$$
* * *
$$

Lia Zanotta Machado é Doutora em Ciências Humanas (Sociologia) pela Universidade de São Paulo (1980), com graduação em Ciências Sociais pela Universidade de São Paulo (1967), mestrado em Sociologia pela Universidade de São Paulo (1979) e pós-doutorado (CNPq) no Institut de Recherches sur les Sociétés Contemporaines (IRESCO) e na École des Hautes Etudes en Sciences Sociales (EHESS), Paris (1992-1994). Professora Titular de Antropologia da Universidade de Brasília desde 1996, é atualmente Pesquisadora Colaboradora Sênior desde 2014. Foi coordenadora da área de Antropologia e Arqueologia da CAPES de 2011 a 2014. Ex-Conselheira do Conselho Nacional dos Direitos das Mulher e ex-membro de Comitê de Monitoramento da Secretaria de Políticas Públicas para as Mulheres (2005 a 2008). Foi Professora Visitante da Universidade de Columbia na Cátedra Ruth Cardoso (2009-2010) e na Universidade do Chile (2002) na Cátedra Rio Branco. Foi também Presidente da Associação Brasileira de Antropologia na gestão 2017/2018. Autora de oito livros, 53 artigos e 45 capítulos de livros, sua obra inclui temas tão diversos como gênero, violência, Direitos Humanos e Antropologia. Especialmente conhecida por seus trabalhos sobre redes e

\footnotetext{
${ }^{1}$ Professora da Universidade de Brasília (UnB).

2 Professora do Instituto de Ciências Sociais da Universidade Federal de Uberlândia (UFU) e do Mestrado em Direito da Universidade Federal de Uberlândia (UFU).

${ }^{3}$ Professor do Instituto de Ciências Sociais da Universidade Federal de Uberlândia (UFU) e do

Programa de Pós-Graduação em Ciências Sociais da Universidade Estadual de Londrina.
} 
saberes feministas, suas contribuições também figuram como referências teóricas para muitos estudos sobre violência contra mulheres.

No entanto, sua estatura científica é bem mais abrangente. Por meio de seu olhar antropológico mais recente, Lia procura identificar as diferentes questões e interfaces entre gênero, sexualidade e os movimentos sociais pelos direitos das mulheres e pelos direitos à diversidade sexual no Brasil.

Como organizadora deste dossiê, Violência \& Gênero, e na companhia do professor Marcio Ferreira de Souza, do Conselho Editorial da Revista Caderno Espaço Feminino, decidimos convidá-la para desenvolver algumas das questões mais significativas do seu arcabouço teórico. Embora realizada por meio de uma conversa, via Skype, a realização de perguntas e respostas nos permitiu sua publicação nesse formato. Foi uma imensa alegria conversar com uma das nossas mais importantes referências teóricas. Seremos sempre gratos a Lia Zanotta pela generosidade com que respondeu todos nossos questionamentos e, principalmente, pelo carinho com que conduziu toda nossa conversa. Agradecemos, ainda, Valéria Cristina de Paula Martins, docente do Instituto de Ciências Sociais da Universidade Federal de Uberlândia, por ter feito a intermediação com a professora Lia.

DRP: Pesquisando seu repertório teórico, que é bastante vasto e profundo, é possível notar um certo ecletismo, embora nas últimas décadas, de fato, se perceba o predomínio dos estudos de gênero. Em sua Antropologia, há várias inquietações, mas a partir dos anos 90 os estudos feministas começam a se destacar. Poderia nos falar um pouco sobre sua trajetória intelectual, de como suas primeiras inquietações sobre a família e o feminismo a levaram a refletir sobre sexualidade, direitos humanos e enfrentamento à violência contra a mulher?

LZM: Primeiro, a sua pergunta em referência ao ecletismo, é em função mais do ecletismo temático? O que você está querendo dizer? 
DRP: Sim. Temático mesmo. Eu fui procurar o currículo Lattes da senhora e eu me surpreendi com textos variados, alguns discutindo especificamente a metodologia da Antropologia, outros, em suas primeiras produções, tratando de individualismo, abordando estudos rurais. Eu achei bastante curioso. Mas depois de um período, principalmente nos anos noventa, eu percebi uma certa concentração de estudos de gênero, ainda que com vertentes variadas; ora estudando o estupro, ora o aborto, ou estudando o movimento feminista e direitos humanos relacionados à gênero. Eu achei incrível.

LZM. É verdade. Tem uma diversidade de áreas. Eu começo trabalhando em Sociologia com desenvolvimento e Estado, assim como escola e política educacional. Na hora que você me fez a pergunta eu fiquei pensando o que atravessa um pouco essa variedade temática. Certamente é a questão do poder e a questão da desigualdade social. Acho que são essas questões, poder, desigualdade social e diversidade cultural, que estão presentes. A minha trajetória em Ciências Sociais na USP sempre foi interdisciplinar. Não foi exclusivamente em Sociologia, por que eu sou um pouco interdisciplinar, mas, enfim, estava focada, portanto, mais na questão do poder e da desigualdade. Em minha tese de doutorado eu trabalho com a questão de uma simbologia do que significa a relação de poder. Por outro lado, dada a minha inserção social no mundo, especialmente diante da preocupação do final dos anos setenta, também me aproximo da questão de gênero, e começo a trabalhar com o feminismo. Minha entrada no circuito acadêmico da antropologia se dá em 1977, pouco depois, diria mais ou menos no final dos anos setenta/oitenta, se junta à entrada na questão feminista. Quando eu estou escrevendo a tese de doutorado eu já buscava alguma coisa que era além de poder e desigualdade; mais precisamente era a questão simbólica, a questão valorativa. É nesse momento que eu venho para Brasília, e que sou convidada para entrar no departamento de Antropologia. Por que até então eu trabalhava na Sociologia. Em São Paulo (Fundação Getúlio Vargas) e no Paraná (Universidade Federal do Paraná) eu trabalhei na Sociologia. Então quando eu faço essa passagem é que realmente junto, diria, o meu feminismo e as minhas preocupações teóricas, sempre um pouco interdisciplinares. É 
nesse momento que a partir da questão simbólica, entram a questão das subjetividades e da diversidade cultural. Quando discuto o individualismo e a família, os primeiros trabalhos que faço já dentro da Antropologia, é que a construção do valor do individualismo me desperta interesse e me leva, imediatamente, à percepção dos modos distintos de se vivenciar os valores do individualismo e, assim, para a questão da diferença das posições sociais do sujeito. É alguma coisa, que eu já vinha estudando na Sociologia, e que não tinha nada a ver com feminismo, mas tem a ver com a questão social, com a desigualdade, mas, principalmente, com a questão da subjetividade. Essa última não se resolve só pelo poder, nem só pela desigualdade. A questão da subjetividade vai se resolver, em grande medida, a partir do contexto geral e também por meio das posições sociais distintas, dos agentes e sujeitos sociais. Então eu acho que é nesse sentido que eu percorro um caminho teórico que, para mim, não é eclético, no sentido de que ele não é disperso, ele é consistente. Ele permite, a partir desse olhar, fazer uma leitura diferenciada, de teóricos distintos e de disciplinas distintas. Eu cito psicanalistas, leio sociólogos, antropólogos, historiadores, filósofos. Esse olhar mais, digamos, interdisciplinar, tem um centro que é ver como se constroem subjetividades no espaço interacional. Palavras do meu tempo de estudante, como estrutura, vêm junto com palavras que fui incorporando no decorrer do meu trabalho de pesquisa, como socialidade, relações e interação social. Para mim não há possibilidade se se analisar sociedades e situações como se fossem uniformatadas, é preciso, portanto, vê-las em movimento enquanto socialidade. É estruturada sim, mas ela não é "uniformatada". Se afirmo categoricamente que as razões da desigualdade de gênero, raça e classe no Brasil e nas nações modernas se devem à estruturalidade histórica hierárquica de gênero, raça e classe inserida não somente na memória social como na história jurídica do Brasil e da maioria das nações, jamais quero dizer que serão sempre assim ou que todos e todas vivenciamos as relações desiguais da mesma maneira. Não há condição de uma sociedade ser uniformatada e inerte. Eu lembro muito um texto do Bourdieu que dizia o seguinte: por que será que nós tratamos a sociedade como se fosse uma 
entidade individual. Esse é o ponto. A sociedade não é nem uma entidade individual como nos advertiu Bourdieu 4 , nem possui aquele controle "maquínico", à la Foucault, onde tudo é controlado, onde há uma "biopolítica"5 em que tudo é moldado. Há estrutura, há controle, há poder biopolítico, vejase hoje como se dá quase uma "necropolítica" na pandemia atual, mas a sociedade não é uniformatada. As interações sociais estão sempre permeadas de conflitos, percepções, sensibilidades distintas que se movem. Eu vejo que toda a noção de poder, de controle social, não pode ser analisada como "caminho de mão-única" porque senão reifica a sociedade. Para não reificar você tem que pensar em mudança e pensar a socialidade através de sujeitos que têm posições sociais diferenciadas. Então vejo que é dessa forma que eu faço um caminho entre teorias das Ciências Sociais, teorias antropológicas fortemente, e a teoria feminista. Eu permito um entrelaçamento reflexivo que muitos não fazem. Para alguns teóricos, o feminismo é visto como alguma coisa que não é antropológica, que não é sociológica, que é uma outra teoria. No entanto, o feminismo é uma perspectiva que não surgiu necessariamente nos próprios campos acadêmicos das Ciências Sociais, mas que é absolutamente compatível com uma forma de se fazer Ciência Social, com uma forma de se fazer Sociologia, com uma forma de se fazer Antropologia. $\mathrm{O}$ feminismo nos permite pensar uma socialidade com posições sociais diferenciadas, sempre com compartilhamento de valores, e, portanto, sempre também com conflitualidades. Conflitos são parte da própria sociedade. Assim, a sociedade se move porque ela não é um bloco de cimento, de concreto. Ela tem inúmeras brechas, movimentações; e porquê? Porque as perspectivas não são as mesmas, ainda que tenhamos o que eu chamo de uma simbologia hegemônica, ou uma ideologia hegemônica, ou uma narrativa hegemônica. Nos últimos tempos eu tenho trabalhado muito com a questão das narrativas.

\footnotetext{
${ }^{4}$ BOURDIEU, P. Razões práticas: sobre a teoria da ação. Trad. de Mariza Corrêa. Campinas, SP: Papirus, 1996.

5 FOUCAULT, M. Nascimento da Biopolítica. SP:Edit. Martins Fontes, 2008. Mais em alinhamento com minhas preocupações, são reflexões do mesmo Foucault sobre subjetividade. FOUCAULT, Michel. O cuidado com a verdade. In: FOUCAULT, Michel. Ditos e Escritos V. Ética, Sexualidade e Política. Rio de Janeiro: Forense Universitária, 2004 e FOUCAULT, Michel O governo de si e dos outros. São Paulo: Martins Fontes, 2010.
} 
Assim como a Spivak ${ }^{6}$, percebo que tem narrativas hegemônicas que querem dizer para todos, que devem servir para todos; mas que não são de todos. Porque as narrativas de cada um têm a ver com a necessidades de se perceber onde se está inserido. Portanto quando um indivíduo faz uma narrativa de se autorretratar, a partir da sua inserção no mundo, essa narrativa não vai bater com a narrativa hegemônica; da elite que quer que todos tenham uma moralidade hegemônica. A narrativa hegemônica faz efeito sobre ele pelo poder que exerce, mas não é a única narrativa à disposição. As narrativas ora se enfrentam, ora se aproximam e movimentam e são movimentadas por percepções, emoções e sentimentos. Há brechas, há mudanças. Esse tem sido um pouco meu pensamento. Quando eu chego no final dos anos setenta/oitenta, eu começo a construir uma forma possível de ver a questão de gênero, que para mim é fundamental politicamente. Naquele momento meu desejo foi fazer um estudo com os movimentos sociais, um estudo das narrativas dos movimentos sociais feministas, mas não só. Eu também analisei as narrativas dos movimentos indígenas na América Latina. Nesse sentido, eu estava desenvolvendo uma forma de analisar diferentes modos de compartilhar. Esse é o grande problema de uma Antropologia, que eu critico, que é aquela totalmente incapaz de ver gênero porque olha o outro e diz assim: ele tem costumes diferentes. Eu não posso analisá-los do meu ponto de vista. Mas ao fazer isso essa Antropologia atribui ao outro o que ele não é. Essa Antropologia vê o outro como se ele fosse "uniformatado". Como se todos os outros, homens, mulheres, crianças, velhos, irmãos, irmãs; todos tivessem uma mesma perspectiva subjetiva em função do compartilhamento de valores. Não é assim. Apesar de participarem desse outro, há nesse interior uma diversidade de posições sociais dos sujeitos, dentro de qualquer sociedade. Esse é o ponto que eu insisto quando discuto a metodologia antropológica ${ }^{7}$. Eu entendo que existem metodologias antropológicas plenamente compatíveis

\footnotetext{
${ }^{6}$ Spivak, Gayatri. Crítica de la Razón Pos-Colonial: hacia una historia del presente evanescente. Madrid: Akal, 2010. Verificar como lido com esta perspectiva em Machado, Lia Zanotta. O Medo urbano e a violência de gênero. In Machado [et al], A Cidade e o Medo. Brasília: Editora Francis/Verbena,2014.

${ }^{7}$ No meu livro Feminismo em Movimento, de 2010 (Editora Francis /Verbena), a questão metodológica da antropologia e do feminismo é analisada no capítulo 3: Antropologia e Feminismo diante da Violência.
} 
com o feminismo, quando estas admitem essa diversidade de posições sociais. Mas ainda tem lugar aquela metodologia antropológica que fica ancorada estritamente nos pais fundadores, pensando, por exemplo na descrição dos habitantes das Ilhas de Trobriand ${ }^{8}$, onde todos seriam moldados pelo rígido compartilhamento de valores, de tal modo que as regras e práticas conformariam igualmente a todos nos seus inamovíveis lugares. Não é possível, senão não teria lugar para conflitualidade que convoca sempre imprevisibilidade, e diferentes perspectivas. Ainda que os valores sejam compartilhados, relações e conflitos são vivenciados distintamente pelas posições sociais diferenciadas de sujeitos. Existe uma forma subjetiva, como diz Strathern ${ }^{9}$, nas outras sociedades, que é distinta da nossa, mas isso não exclui que haja posições sociais, de agência, diferenciados, tanto lá, como aqui. Enfim, para mim esse é um mote principal. Eu falo sobre a questão de gênero e sobre a questão da violência, mas também me permito pensar outras coisas que não necessariamente apenas gênero e violência; embora a maior parte do que eu faça é isso, mas eu faço muito além disso e também um pouco mais amplamente.

DRP: Com certeza. Eu achei muito interessante esse debate sobre as prioridades metodológicas antropológicas e as prioridades metodológicas feministas e de gênero que a senhora discute no livro Feminismo em movimento. Eu sinto isso também, às vezes, quando estou dialogando com a Antropologia em alguns temas de violência, como com a Alba Zaluar, por exemplo, com quem eu dialoguei sempre muito. Ficou muito claro para mim, no livro, como a senhora coloca esse dissenso com essa matriz antropológica. De buscar olhar para o outro sem que isso não signifique reificar a diferença.

LZM: “Uniformatar” é a expressão que eu uso, não sei que outra palavra poderia ser. Nesse sentido, reificar seria transformar em uma coisa uniforme. Transformar a cultura do outro em algo uniforme. É como voltar para

\footnotetext{
${ }^{8}$ Estas ilhas e seus habitantes foram objeto de estudos do antropólogo Bronislaw Malinowski, a partir do qual produziu um dos clássicos da antropologia do século XX, Argonautas do Pacífico Ocidental (1922).

${ }^{9}$ Strathern, Marilyn. The Gender of the Gift. Berkeley and Los Angeles: Univ. Of California Press, 1988.
} 
Durkheim ${ }^{10}$. É retornar a uma ideia de que se tem dois tipos de sociedade. A sociedade "a la Durkheim", a sociedade orgânica, e a comunidade tradicional, de solidariedade mecânica que é comunitária, mas, unívoca e "uniformatada". É voltar a Radcliffe-Brown ${ }^{11}$ e os sentimentos uniformados dos andamaneses. Não é assim. Esse foi só o nosso olhar ocidental que se fez pela diferença e que reificou a diferença. E isso é uma armadilha. Uma armadilha teórica de olhar o selvagem ${ }^{12}$ como se fosse uma coisa "uniformatada". Como essa armadilha impacta na discussão da violência? Você tem muitos antropólogos que dizem: gênero só existe nas nossas sociedades ocidentais. Violência também só existe nas nossas sociedades ocidentais. Violência contra mulher, então, só na nossa, pois esse termo foi inventado aqui. O termo gênero foi inventado na sociedade ocidental? Foi. O termo violência contra a mulher também foi. Mas muitos outros termos também o foram. A noção de trabalho também foi inventada por nós. As sociedades tradicionais não tinham a noção de trabalho, por ser um trabalho abstrato. Isso não nos impede de fazer estudos antropológicos das formas de trabalho e lazer em sociedades tribais e como são distintos das nossas formas. Como as concepções são diferentes podemos fazer comparações. Da mesma forma para a questão da violência. Ela também existe nas sociedades distintas das nossas, assim como a questão de gênero. Nós temos um gênero desconstrutivo, mudamos, criamos uma outra forma de olhar para o gênero. Não pensamos os gêneros fixos a sexos ou a pessoas. Os gêneros podem se metamorfosear, se multiplicar conforme os sujeitos e as relações. Mas se olharmos para o gênero simbólico, ou seja, numa divisão de gêneros que se supõe mais fixa e que também é uma noção que está entre nós, podemos dividir o mundo, os objetos, os animais e não somente as pessoas em gêneros distintos simbolicamente. $\mathrm{O}$ que eu digo é que gênero é simbólico, seja desconstrutivo ou não. Gênero permite relacionar, portanto gênero não é só dominação, gênero não é só poder. Mas gênero é também poder, gênero é também dominação. Assim, quando se quer simplificar o mundo dizemos que

\footnotetext{
${ }^{10}$ Durkheim, Émile. Da divisão do trabalho social. SP: editora Martins Fontes, $4^{\mathrm{a}}$ Edição - $2010\{1893\}$. 11 Radcliffe-Brown, Alfred Reginald. The Andaman Islanders. a study in social anthropology. Cambridge: University Press.1922.

12 Alerta feito por Trouillot, Michel. Anthropology and the Savage Slot: the poetics and politics of otherness. Santa Fé; School of Research Press, 1991.
} 
aqui tem violência e lá não. Essa é uma discussão enorme, porque se olharmos para uma outra cultura negando a existência de violência, silenciamos essa própria cultura. Nós perguntamos para as mulheres dessa cultura se existe violência? Perguntamos como elas sentem? Elas podem até achar natural que um homem bata em uma mulher quando ela não faz o que lhe é esperado. Pode considerar normal? Pode. Mas isso não significa que essa mulher não sinta como humilhação, desconsideração, agressão. E há antropólogos que creem que se a violência doméstica é considerada "normal", isto é, é esperada, então ela não é violência ${ }^{13}$. Nesse sentido eu entendo que ainda é preciso rever bastante o nosso olhar ocidental em relação as outras culturas. Então quando se diz, às vezes, que o que tem aqui não tem lá, tudo que tem lá não tem aqui; isso, para mim, é fazer uma Antropologia muito rasteira. Para mim, não é uma boa metodologia antropológica.

DRP: Ótimo. A segunda pergunta é mais sobre os trabalhos recentes. Seus trabalhos sobre o confronto político entre as argumentações feministas e os discursos fundamentalistas sobre o aborto, ganharam bastante projeção recentemente. Trata-se de tema bastante espinhoso e que tem produzido rompantes passionais de todo gênero, como ameaças e retaliações a quem tem estudado isso no momento atual. Em suas palavras estamos diante de "forças neoconservadoras cada vez mais mobilizadas em impor uma moral religiosa sobre as mulheres". Poderia nos falar um pouco como essa imposição representa um retrocesso, não só ao direito ao aborto, mas também dos direitos das mulheres?

LZM: Quando eu estava fazendo essa pesquisa buscando analisar o debate entre o aborto como direito e o aborto como crime diante do retrocesso neoconservador ${ }^{14}$, na verdade ela abrangeu dois momentos. $\mathrm{O}$ primeiro foi quando houve a tentativa do movimento feminista de conseguir, inclusive com o apoio do Poder Executivo, a legalização do aborto. Parecia possível. Era o

13 Comparo visões distintas de antropólogos e antropólogas sobre violência doméstica em sociedades indígenas e não ocidentais no capítulo 3 de Feminismo em Movimento, 2010.

${ }_{14}$ Machado, Lia Zanotta. $O$ aborto como direito e o aborto como crime: o retrocesso neoconservador. Cadernos Pagu, v.50, p.e17504, 2017. 
governo petista, o governo Lula. Parecia possível, mas aí estouraram as denúncias do mensalão, que tornaram a possibilidade do Executivo nos apoiar muito pequena. Naquele momento nós (feministas) chegamos a entregar o projeto para a liberação do aborto para a câmara dos deputados, para a deputada Jandira Feghali, que já estava examinando outros projetos, contra e a favor da legalização do aborto. Jandira inseriu a nossa minuta de projeto nesse bloco. Assim, a primeira parte da minha pesquisa é sobre esse momento político crítico, em que se faz uma audiência pública em 2005 onde é possível perceber entre deputados e especialistas convidados uma parte a favor da legalização do aborto e uma parte contrária. Uma primeira análise dessas entrevistas aparece já em textos meus de 2008 e 2010. Em 2016 e 2017 retomo essas entrevistas e as junto e comparo com toda a discussão na internet. Faço tanto uma análise das narrativas desse momento de 2005 em que deputados e especialistas, de um lado e de outro, fizeram sobre o aborto quanto as comparo com o debate na internet do segundo momento de 2015 a 2017. São muitas as narrativas antiaborto encontradas nesse espaço. Vou pinçar algumas blogueiras feministas para dar um certo confronto, mas a minha análise fica mais nas narrativas antiaborto. O que eu vejo, que já era possível perceber lá em 2005, continua em 2015, 2016, 2017. Contudo fica muito claro que agora temos uma concepção fechada de que se é contra o aborto é também contra a posição da mulher. Por que a parte contrária ao aborto geralmente usa o discurso dos direitos humanos, que é um discurso nosso, progressista, pelo menos meu, mas distorce o discurso dos direitos humanos e vai defender o direito do feto. E acaba transformando o feto em uma entidade já formada, autônoma, que só falta sair andando e falando. Quando na verdade se você olha o que está por traz dessa fala e dentro dessa fala, claramente, é toda uma forma conservadora de insistir que a mulher fique em casa. Despontam discursos, ao mesmo tempo, sobre o aborto e sobre a posição da mulher. A mulher não pode ser a chefe da casa, ela tem que ser ajudante. Aquela que se separa é aquela que quase traz o demônio para casa. Porque ela arrebenta e desestrutura. Nesses discursos conservadores a mulher desaparece como sujeito, ela ocupa só o lugar da esposa, controlada pelo marido. A mulher é 
definida pelo papel de esposa obediente e que ajuda o companheiro, inclusive mais do que de mãe; nem falam tanto em mãe. Falam em mãe quando dizem: a mãe desarraigada que quer tirar o filho dentro de si, quando na verdade, esse filho não é um filho, é uma formação em seu início, ou é um zigoto ou é um embrião que não tem formato definido ou mesmo um feto no limite das doze semanas de gestação, incapaz de autonomia ou pensamento. E o absurdo é que essa mulher, que está tendo esse pequeno início de formação no útero, é uma mulher formada, com vida vivida, às vezes com quatro filhos, sem condições de sobrevivência, às vezes com problemas de saúde, e que, naquele momento, não pode vir a ter o filho ou não o deseja naquele momento. Está sendo tirada da mulher a possibilidade de pensar sobre uma gravidez indesejada. Essa mulher não pode existir. O direito do zigoto/embrião/feto é pensado como direito absoluto. $\mathrm{O}$ direito da mulher com gravidez indesejada é absolutamente negado, seja qual for a razão, inclusive ter sido estuprada ou estar em risco de vida como já permitido legalmente pelo Código Penal Brasileiro. É proibida a existência da mulher que tenha vontade, que seja sujeito. Ela só pode ser reprodutora. É nesse sentido que eu vejo um controle absolutamente fantástico deste conservadorismo. $\mathrm{Eu}$ chamo de neoconservadorismo porque você pode dizer que é uma posição conservadora que a sociedade já tinha, mas não com essa dinâmica. Antes os conservadores defendiam seus valores, agora existe uma exaltação que obriga os outros a seguirem seus valores como os únicos próprios. Esse neoconservadorismo também tem uma mídia toda a seu favor. Por isso é uma reorganização dos valores conservadores. Esses valores, no passado, podiam ser tão conservadores quanto os de agora, mas não eram tão disciplinadores. Antes os valores conservadores eram na linha do "sempre foi assim", "vamos continuar assim", mas havia uma abertura para a contestação. O modo pelo qual, socialmente, o conservadorismo foi perdendo espaço, para um certo progressismo da posição da mulher, movimentou a sociedade toda. Esse conservadorismo não tinha necessidade ou vontade de uma construção de narrativa, que precisava de mídia, que precisava de força, que precisava de dinheiro, que precisava de tudo, até de fake news, para se fazer valer. Hoje 
vivemos ameaças incríveis. O neoconservadorismo precisou dessa rede, precisou de fake news, precisou de ameaças, e precisou também reorganizar a visão conservadora. E nesta reorganização explícita nas redes, os defensores contrários ao aborto passaram a silenciar a voz das mulheres. Hoje, para esse neoconservadorismo, o retrato da mulher é a mulher sem voz, a mulher sem desejo, a mulher que é uma máquina reprodutora. E uma máquina obediente. Então por isso que eu digo que é uma proposta de controle das mulheres, além de ser contra o aborto. Hoje quem é crítico do feminismo diz que as feministas estão querendo disciplinar a sociedade de uma outra forma. Dizem o mesmo dos antirracistas e dos que defendem a população LGBTQI+. A grande pergunta é: será que esses novos movimentos sociais estão disciplinando? Eu diria que não porque eles não impõem uma moralidade única. Eles estão querendo seu lugar ao sol. Estão querendo o respeito, e não impor uma moralidade. Mesmo todas nós que somos a favor da legalização do aborto, não estamos pensando que todo mundo deve abortar. Que isso! De jeito nenhum! Abortar é uma coisa muito difícil. Mas o aborto tem que ser possível. No momento em que o direito do feto se torna absoluto, uma mulher que tem um feto anencefálico, por exemplo, se vê obrigada, mesmo não querendo, a continuar a gestação, ainda que esse feto nasça e dure um dia, ou dois, ou até nenhum.. Na verdade, escrevi sobre isso ${ }^{15}$. Além da tragédia de se ter um feto anencefálico, há também a tortura de se ver obrigada a manter uma gestação assim até o final, morram quem for. Esse direito, quando absoluto, se transforma em uma moral que é impositiva para todos e em tudo. Ela é duplamente impositiva: para todos e em tudo. Essa é uma questão. Assim, enquanto o feminismo tenta introduzir uma nova forma de tratar a gravidez indesejada, introduz e não obriga. Já o neoconservadorismo procura estabelecer uma moral disciplinadora impositiva. Uma moral única para todos, e sendo olhada de lugar nenhum. De que lugar podemos dizer que uma pessoa é obrigada a fazer isso, obrigada àquilo? Recordo de uma frase de Haraway ${ }^{16}$ que diz algo nesse sentido: "com que olhos você vê, com que sangue

\footnotetext{
${ }^{15}$ Machado, Lia Zanotta. Da Tragédia ao Direito à Supressão da Tortura. Série ANIS, v. 58, 2008.

16 Haraway, Donna. Simians. Cyborgs and Women: the reinvention of nature. New York: Routledge, 1991.
} 
você vê e decide sobre o outro?" As perspectivas feministas, antirracistas e a favor dos LGBTQI+ nos orientam a olhar a partir de si e a partir da sociedade, procurar essa convivência plural, são, portanto, contra uma moral impositiva. Os feminismos criam o que eu chamo de nova ética. Os movimentos sociais pela diversidade sexual, antirracistas e feministas criam novas éticas, éticas diversas, mas não uma moralidade impositiva.

DRP: Sim. Recentemente funcionários do Ministério da Saúde, foram exonerados porque assinaram um parecer técnico sobre atendimento à saúde da mulher durante a pandemia. O documento assinado por eles tratava dos serviços de saúde sexual e saúde reprodutiva que continuam atuando no período de pandemia. Eles foram afastados porque simplesmente deram uma informação de continuidade de um serviço público voltado para a mulher.

LZM: E eu vou dizer uma coisa: acho que não teve tempo no mundo em que mulheres não abortaram. Assim como não teve tempo no mundo em que mulheres não reproduziram, ou que não tiveram muitos filhos. Isso faz parte da vida social. Em determinados momentos não é possível levar adiante uma gravidez indesejada, ao mesmo tempo que é absolutamente prazeroso você ter um filho de uma gravidez desejada. É importante analisar essas narrativas. Não se está sendo apenas contra o aborto como a igreja sempre foi. É mais do que isso. Hoje estamos diante de uma forma impositiva, de tornar obrigatório, fiscalizar, se possível matar, prender; fazer o que for feito com essas mulheres. $\mathrm{Eu}$ acho impressionante como essa modernidade tecnológica e autoritária permitiu aos conservadores refazerem a sua fala e seus instrumentos de conviç̧ão, instrumentos de controle; eu diria.

MFS: Bem Professora Lia, outro exercício de reflexão muito importante em seu repertório cientifico é o estudo das masculinidades, uma abordagem relativamente recente, aqui no caso brasileiro, que se expandiu mais nos anos oitenta, mas muito importante nos estudos sobre violência contra as mulheres. A senhora pode nos contar um pouco como foi esse exercício de ouvir relatos de prisioneiros apenados por crimes de estupro e de agressores 
acusados de violência física contra suas companheiras? Ou outros relatos que a senhora quiser trazer da sua experiência de pesquisa, focando nas masculinidades, por exemplo.

LZM: É um negócio muito difícil de ouvir. Talvez mais difícil tenha sido ouvir os relatos de apenados por estupro. Isso aconteceu durante uma pesquisa feita no $N E P e M^{17}$, em que participavam professoras e estudantes. Nossa entrada na prisão foi possível, para, de alguma forma circunscrever aqueles que foram apenados por estupro. Foram feitas no mínimo duas entrevistas com os apenados, deixando-os falar. As perguntas eram feitas e se deixava que falassem, discorressem um pouco, apenas com perguntas orientando. De uma entrevista para a outra, foi possível perceber mudanças nas narrativas dos estupradores, sobre aquilo que eles fizeram. Tanto tinham uma ideia de que a coisa não foi nada demais, quanto a ideia de que simplesmente aconteceu. Também, em alguns casos, havia um arrependimento na hora, mas pequeno, pois predominava muito mais a leitura da oportunidade se apresentando. Um dos apenados por estupro que eu analiso, mostra um certo arrependimento, mas sem muita conviç̧ão. "Olha eu comecei, tive a oportunidade, eu estava ali no meu canto, ela apareceu, altas horas da noite, então eu fui lá. Quando já estava lá, pensei por que eu vou fazer isso". No entanto fez, e depois saiu correndo. Foi o único, que me recordo, que falou em um certo arrependimento. Os outros falavam: "é a mulher que estava sozinha, à noite, na estrada”. Há toda uma leitura de que as mulheres é quem devem se cuidar. Ao narrarem dessa forma, esses homens estão respondendo a uma narrativa hegemônica. Diziam "que a mulher estava sozinha", "a mulher era quem queria", "a mulher quem provocou". Eles diziam isso sobre qualquer circunstância. As mulheres não foram entrevistadas, mas lemos os relatórios dos boletins de ocorrência. Se uma mulher contava, por exemplo, que estava com tanto medo que havia

\footnotetext{
17 Núcleo de Estudos e Pesquisas sobre a Mulher é vinculado ao Centro de Estudos Avançados Multidisciplinares (CEAM) da Universidade de Brasília (UNB). Além de vários textos em periódicos publicados por professoras e estudantes que fizeram parte da pesquisa, é o livro Violência, Gênero e Crime no DF organizado por Suárez, Mireya e Bandeira, Lourdes, Brasília: Editora da UnB e Paralelo 15, 1999, que permite visibilizar o esforço de pesquisa conjunta com diversas autorias não só sobre violência sexual como sobre diferentes formas de violência de gênero. Redigi nesse livro o capítulo: Sexo, estupro e Purificação.
} 
urinado na roupa, ele contava que ela estava com a saia levantada quando ele chegou perto do ponto de ônibus. As narrativas masculinas sempre distorciam a situação. $\mathrm{O}$ fato de se estar morrendo de medo, e urinar nas calças, que é o que contava a mulher, era interpretado pelo homem como uma facilitação da mulher. Ele dizia que estuprou porque ela estava a noite, em um lugar inseguro, sozinha, e ele fez aquilo porque ela era uma mulher vadia. Ou então ele dizia o seguinte: "olha eu não queria muito, mas o meu colega que estava junto pegou ela primeiro, então eu tive que fazer". Tem também os olhares masculinos entre si, em que um dá prestigio ao outro. Se o homem não estupra a mulher que foi estuprada pelo seu amigo ou companheiro, ele, que está sendo desafiado, acaba perdendo prestígio. O que ficou muito claro para mim é que a questão do estupro era uma questão de controle, de poder e também de prestígio entre os homens. Essa última noção, que talvez não seja muito comum, e que aparece em outros trabalhos meus, é a questão do prestígio. Isso também acontece nos feminicídios, ou seja, os homens são prestigiados em relação aos outros, quando eles matam suas mulheres ou quando ameaçam suas mulheres. Quando se torna público, ou quando ele mesmo conta, que está desconfiando que sua mulher tem outro alguém; ele tem que fazer alguma coisa. Assim, o controle das mulheres, não é apenas pelo controle, é também para atribuir prestígio entre homens. Isso ficou claro para mim na questão da masculinidade, em relação com as mulheres. Não é só com relação ao estupro, os feminicídios também são assim. Eles dão prestígio entre os homens. Há uma circulação de prestígio entre os homens, controlando as mulheres. Isso eu vejo que é uma questão muito importante e resolve muito algumas outras questões. A gente fica pensando como é que pode ter um estupro coletivo? O estupro coletivo reúne esse vigor do prestígio entre homens de uma forma incrível. Por isso a questão do prestígio é fundamental. Outra questão talvez não tão inovadora, mas que me citam muito por isso, é o "travestimento ou transformismo da noção do estupro".

DRP: Isso. Essa é a próxima questão 
LZM. Como é que se traveste a noção de estupro? Transformando-a, de alguma forma, em algo que é banal. Voltando aos estupradores, eles nos mostravam o estupro como uma coisa simples. Eles banalizavam e depois diziam que a mulher também queria. Em uma entrevista que analisei um homem respondeu a porque teve relação sexual: "Bom, ela queria”. Daí se segue a pergunta: mas como é que você sabe que ela queria? Ele disse "Ah...eu disse pra ela que se ela não me beijasse eu a matava. Daí ela me beijou”. Isso quer dizer que ela quis? Para esse homem sim, pois ela podia não fazer. Olha o imaginário enlouquecido de que na verdade é uma relação como outra qualquer e que os dois querem. Essa é a banalização. Na visão desse homem, os dois querem, mas o seu querer pode mais do que o dela. No senso comum hegemônico, na relação sexual é ele que tem que ter a iniciativa. Então no estupro, eu costumo dizer, é como se fosse "natural" que quem tem que ter a iniciativa é o homem. Nesse sentido, se ele é quem tem a iniciativa, a ela só cabe dizer não. Mas o não para a mulher é coisa de somenos, porque dizer não faz parte do papel social da mulher. No imaginário masculino, uma mulher deve sempre dizer não, mesmo que ela não queira realmente dizer não. Então aí está o transformismo da noção de estupro. O estuprador faz parecer ao outro, no caso às mulheres, que elas também queriam, mesmo que digam não. E esse intento perverso de dizer que a mulher também queria e de que o desejo do homem é o que importa se sustenta na ideia de senso comum hegemônico de que o corpo feminino é o apoderado e o masculino é o ativo. Voltando à sua pergunta da masculinidade, de forma mais geral, eu fiz entrevistas com homens nas delegacias especializadas, em que as mulheres estavam fazendo denúncia de agressão doméstica e os homens agressores vinham dar seu depoimento. Alguns desses homens foram entrevistados. Alguns diziam uma palavra que eu achei interessante: "bicho homem". "O bicho homem é assim mesmo". "Tendo a oportunidade pega". Então ele é. O bicho homem é assim. Um entrevistado me falou da irmã que, segundo ele, foi estuprada por um outro homem. Ele foi lá e bateu nele, porque ele não pediu consentimento para namorá-la. Sem o consentimento, como é que ela estava namorando, como é que ela teve relação sexual. Ele vai e arrebenta o suposto namorado da irmã. 
E esse mesmo homem, que me conta isso, é o também o homem que está sendo denunciado pela mulher. Veja como a posição masculina vai depender do lugar dele em relação à família. A relação de parentesco é fundamental para se dizer, se o ato cometido foi ou não um estupro. Se for um outro homem que tem relação com a irmã e ela diz não ter consentido é estupro, mas se for ele com uma mulher que diz não querer, esse não, nada significa, ele está apenas pegando uma mulher. Ele pode. Essa ideia de que a definição do estupro pode estar sempre em travestimento como se fora uma relação sexual banal, passa também pela posição do sujeito que fala na relação de parentesco. $O$ masculino se coloca em relação ao feminino, no lugar da lei, do poder e do controle. Gostaria também de falar sobre o lugar do masculino como lugar de disputa e desafio entre homens. Os desafios dos homens entre homens é uma coisa que sempre aparece. Sobre esse tema, também costumo usar outra expressão: “o gênero da violência”. A noção de violência de gênero está geralmente vinculada à violência dos homens contra as mulheres (esse é o uso mais corrente da expressão). Mas nós também temos uma outra coisa que é violência entre homens. Para tratar da violência entre homens, prefiro utilizar e enfatizar o conceito de que todo ato e toda relação de violência têm gênero. Chamo de "o gênero da violência”. Eu fiz alguns entrevistas com homens internados em um hospital porque vieram de uma briga de rua. Os dois, que estavam em locais diferentes, portanto um não ouvindo o outro, me disseram assim: "vá ouvir o outro", "vá ouvir o outro em quem eu bati", "vá ouvir o que ele vai dizer". "ele está pior do que eu”. E aí um dos homens me disse: "uma boa briga não é violência". Eu então disse a ele, você está todo arrebentado, isso não é violência? "Ah, eu estou sofrendo, ele foi violento, foi violento, mas foi uma boa briga”. Veja como a ideia é de disputa de poder. O que eu chamo de "o gênero da violência" masculino em relação ao masculino é o desafio. Você disputa o poder. É filho disputando com o pai. O filho diz assim para o pai: "agora você não bate mais, eu tenho doze anos, agora eu é quem vou bater em você". Isso é muito comum! É absolutamente comum. Em minhas pesquisas sobre família, apareceram também muito a questão dos desafios entre homens e do controle dos homens sobre as mulheres. Em 
determinado momento tem-se a construção do masculino como violento, em que ele dirige a violência para homens, e o faz por meio do desafio. E para mulher é o controle. O controle dele sobre a mulher permite também a circulação de prestigio entre homens. Eu chamo de "o gênero da violência" pois não há violência sem gênero. Você joga o seu gênero no modo de ser violento e na relação social. E não só pelo seu gênero, mas pelo gênero que o outro tem, com quem você está sendo violento. É completamente diferente, por exemplo, a disputa entre dois irmãos, da disputa entre um irmão e uma irmã. Eu estou fazendo uma pesquisa agora sobre a Lei Maria da Penha e a violência de gênero tem aparecido entre irmãos e irmãs. Há quem diga que, por exemplo, desentendimento financeiro entre irmãos não é violência de gênero. Claro que é! Eu observei, nessa pesquisa, que uma irmã cobrando um irmão também escancara a questão do controle masculino. A irmã diz: "você tem que pagar o aluguel”. Ele diz: "você veio morar aqui, você tem que pagar. Ela diz: "Paguei a minha parte, mas você não pagou nada, e você tem que pagar”. E ele não paga e a imobiliza na cama. Ela com medo decide se mudar. Aí também está presente a ideia de controle, mesmo entre irmãos. Ainda na questão da masculinidade, o que eu vejo é que ela é muito construída sobre o outro. Às vezes eu brinco, que as masculinidades estão muito carentes (risos), porque elas dependem sempre do prestígio do olhar do outro. Eu fiz análise também, de relatos de adolescentes em situação de medidas socioeducativas restritivas de liberdade. O que eles me dizem: "eu ando na rua e ninguém olha para mim", "todo mundo tem que abaixar o olho no meu pedaço". Uma vez nós fizemos um seminário em reunião da ABA onde Alba Zaluar, e eu falávamos, do ethos guerreiro. Está muito presente um ethos guerreiro do desafio entre homens e um controle das mulheres que também se constitui em prestigio entre os homens. Por isso que eu digo, que a masculinidade é carente porque ela está sempre dependendo do outro, homem ou mulher. Na nossa cultura, em defesa da honra, o homem pode matar a mulher. A desonra dele está no fato da mulher o ter deixado. Quer dizer, é uma carência absoluta. Ela não obedece, ele desestrutura. Ele é muito dependente dessa interação e, portanto, com muita raiva, com muita violência e com pouca introspecção das 
emoções (ele não sabe lidar com as emoções), o homem exterioriza sua masculinidade. Então eu trato essa questão a partir da ideia de poder, controle e desafio da masculinidade. Outra forma de refletir sobre a questão da masculinidade é discuti-la tendo em vista características da nossa modernidade contemporânea, que passou por uma espetacularização. Quando eu começo as pesquisas sobre violência, e sobre família, nos anos oitenta e noventa, é possível perceber que o controle sobre a mulher acontece principalmente dentro de casa. Nos anos dois mil, essa mesma sociedade está cada vez mais espetacular. Eu tenho um relato de um homem que diz assim: "eu entrava em bares com a minha namorada, para puxar briga". Ou seja, ele a levava como um troféu, e se alguém mexesse com ela, ele saía dali pegava uma arma, um bastão, o que fosse, e voltava para brigar. E também ficava feliz com a briga. Isso me fez pensar em tantos outros autores, filósofos e sociólogos da sociedade do espetáculo ${ }^{18}$, o quanto nós estamos vivendo, e hoje cada vez mais, com a questão da exposição das imagens. Hoje um homem mata não apenas porque tem um ciúme doentio, um medo louco de perder o prestígio, de deixar de controlar sua mulher; mas também para se exibir. Sua violência é também para mostrar seu prestígio. Para mostrar no bar quem ele é, para o outro homem. Trabalhando sobre as masculinidades no Brasil, estou percebendo que nós estamos em vários tempos ao mesmo tempo. A gente está no tempo do conflito em função da defesa da honra, nós estamos também diante da noção do prestígio, que já existia, mas agora é o prestígio espetacular. É um espetáculo para os outros verem. Não é que o homem sente ódio, vai lá e mata. Ele agora também produz a cena. Ele não apenas está em uma cena de violência, ele produz o cenário e a cena para poder desafiar o outro. Assim tenho desenvolvido a questão da violência. Busquei entender não só pela violência contra as mulheres, mas também por meio dos homens e entre homens. Entender o que faz o homem querer ser violento, controlar as mulheres e desafiar os outros homens tão incessantemente.

${ }^{18}$ Debord, Guy A Sociedade do Espetáculo. Rio: Editora: Contraponto, 1997 
MFS: Nos seus estudos sobre família a questão da honra já estava presente. Nos estudos dos anos oitenta. Eu me lembrei de um texto seu, talvez ali já estivesse germinada essa discussão das masculinidades. Estou pensando nisso agora.

LZM: Ah sim, com certeza. Já estava pensando nisso. Inclusive porque eu comecei estudando famílias e fiz muitas entrevistas com homens e com mulheres. Impressionante o que uma mulher me disse do seu marido, eu jamais me esqueço o que ela me disse assim: "a honra dos homens, quando depende deles mesmos, ela pode ser resolvida. Meu pai bebia muito, parou de beber, voltou a ser um homem honrado. A mulher, se está com um homem e o deixa, ou alguém diz que traiu, a desonra está feita para sempre. Ela está perdida”. O prestígio do homem, se ele era desonrado, se resolvia com a expulsão desta mulher. Ele a mandava embora. Isso aconteceu muito quando eu estudava família. Teve um homem que me disse: "Ah minha irmã está perdida. Ela teve que sair daqui, teve que ir para São Paulo. As mulheres também entendiam, voltando um pouco na questão das agências, que a outra, a irmã, estava perdida. Mas a posição que ela tinha, para essas mulheres, era de coitada. "Teve que ir embora, coitada". Embora dissessem que era normal que o marido tivesse expulsado, a viam como coitada. Enquanto aquele que mandou aquela mulher embora estava perfeito. É a imposição. Sim, a questão da honra apareceu muito nos meus estudos sobre família. Comparando classe média e classe popular, pude perceber que não eram situações tão opostas. Havia configurações diferentes na classe média e na classe popular, mas havia também configurações semelhantes. Não dava para dizer que na classe popular não havia gênero, ou o gênero era tradicional; e na classe média era mais progressista. Nada a ver. Tem configurações bastante distintas e a questão do individualismo perpassa as duas, mas era construída distintamente. Um pouco isso que eu trabalhei. Sem nunca fazer oposições binômicas, porque nós estamos em uma sociedade, toda ela, entrelaçada.

DRP: Eu vou passar agora para o livro Feminismo em Movimento. Ainda que a professora Lia já tenha falado sobre as prioridades metodológicas 
antropológicas, e também do movimento feminista; o livro também traz um debate interessante que é justamente fazer uma crítica à desigualdade de gênero e, ao mesmo tempo, respeitar a diversidade cultural. Como fazer isso, professora? Como é fazer crítica à desigualdade, que como a senhora mesmo disse é o eixo central da sua produção e, ao mesmo tempo, respeitar a diversidade cultural?

LZM: Eu acho que esta é uma questão teórica, antropológica, mas também é uma questão que vem de uma reflexão sobre a minha inserção no mundo. Envolve também a questão dos direitos humanos, quer dizer, isso aflige não só os acadêmicos, os antropólogos, os sociólogos, etc., mas todos buscam construir direitos humanos em escala internacional. Estou fazendo uma tergiversação, mas vocês me voltam para o rumo da conversa. Quando eu estava escrevendo esse livro eu estava dando um curso na Columbia University, em Nova Iorque, sobre gênero e diversidade cultural. O que aparecia muito presente nas falas dos meus estudantes de pós-graduação lá, em 2009 e 2010, eu não encontrava aqui em Brasília, junto aos meus estudantes - pode ser que eu encontre agora. Lá discutia-se a ideia de que direitos humanos era uma coisa muito americana. Portanto, pensar em direitos humanos para a África, para a Ásia e mesmo para a América Latina era um contraste. Eles pensavam: Como pensar os direitos humanos para África, para a Ásia quando a diversidade cultural é tão grande? Nessa visão, os direitos humanos são vistos como extremamente individualistas (e americanos) e não se pode impor uma leitura individualista de direitos humanos para sociedades que não são tão individualistas. No livro Feminismo em Movimento eu faço uma referência de como as diversas conferências internacionais de direitos humanos são resultado de negociações intergovernamentais em que a visão americana muitas vezes não teve prevalência e como trabalharam com a noção de diversidade cultural e dos direitos das mulheres. Se em 1993 uma Conferência da Nações Unidas sobre Direitos Humanos em Viena, delibera claramente que deve prevalecer o direito das mulheres sobre qualquer tradição cultural que impedisse tais direitos, posteriormente começam a despontar discussões no sentido de 
ascender ou um ou outro. Tem determinadas formas de se falar em diversidade cultural, inclusive em decisões de reuniões na UNESCO (depois eu participo de uma reunião da Comissão Sobre o Status da Mulher, em 2012), que insistem em discutir o confronto dos direitos das mulheres em nome da diversidade cultural. A contradição cresce dentro das Nações Unidas, nas próprias comissões de status das mulheres, porque você tem governos que dizem não à prevalência dos direitos das mulheres. Começa a surgir o entendimento de que se as mulheres tiverem direitos em determinados países, perde-se a tradição cultural nesses lugares. Eu mesma ouvi de representantes de determinados países essa fala em reuniões da Comissão de Status da Mulher. Então, existe essa contradição. Volto à minha referência às aulas na Columbia University. Meu cuidado, pensando nisso, foi ter uma resposta que pudesse dar espaço para os direitos humanos das mulheres e que tivesse base também no princípio de respeito à diversidade cultural da perspectiva da antropologia. É um pouco tentar construir um lugar que seja factível para o feminismo e para a antropologia, de falar sobre a possibilidade de se casar direitos humanos e direitos das mulheres. Agora, esse "casamento" é simples? Não. É preciso "ressignificar". Eu usei esse termo mesmo, que agora está em moda, porque é preciso dar conta de uma transculturalidade ou interculturalidade. Esses direitos das mulheres podem ter algo em comum, mas também algo específico. É possível fazer isso. Eu acho que a gente pode pensar uma ressignificação cultural e acho que isso é fundamental. Eu me lembro que quando eu fiz um trabalho para o UNIFEM ${ }^{19}$, no ano 2000, de análise de projetos para direitos das mulheres em regiões onde havia a prática da excisão do clitóris, uma mutilação corporal difícil de pensar. A questão era se podíamos impor um posicionamento diferente? Mas impor o que? Daí quando comecei a olhar os trabalhos já desenvolvidos sobre o tema, em que se ouviram mães, avós, filhas, pais, avôs, maridos, é possível captar uma variedade de percepções. Então não existe uma única visão sobre a excisão do clitóris, mesmo entre aqueles (as) inseridos nessa prática. Há a mãe que não

19 United Nations Development Fund for Women (Unifem) hoje substituído pela UN Women (ONU Mulheres). 
quer que a filha seja excisada e a avó que quer. Tem também a avó que não quer, tem marido que não quer, tem marido que exige. Enfim, porque sempre se perde ou se ganha alguma coisa. Se a excisão na mulher não é feita, sua filha, sua neta, sua irmã poderão ter um casamento menos importante. Enfim, perde-se alguma coisa. Contudo o que eu digo é que nesse jogo, em que as mulheres são vítimas de violência doméstica ou da violência da excisão do clitóris, elas sempre perdem. Elas ganham uma vida e ganham o fim da violência quando denunciam o homem agressor, mas perdem muita coisa positiva que imaginavam ou mesmo tinham em termos de socialidade e de vida familiar. É assim sempre, ganha-se alguma coisa e perde-se outra. São esses conflitos, essas contradições que dão existência a vida social. Assim, não são meramente contradições abstratas, diversidade cultural versus gênero. Não é isso! Nós é que fazemos esse exercício equivocado. Porque é muito mais. São contradições e ambiguidades enormes na vida cotidiana que atingem um monte de pessoas. Sendo assim, não é possível que um antropólogo diga assim: “Não toque! Não toque nesse assunto, deixa lá porque eles vivem bem”. Eles não estão todos e todas bem! Porque há uma variedade de pensamentos em relação a essa situação sobre a excisão do clitóris. Mesmo se não tivessem interação com a sociedade moderna. Ainda assim, teriam, em seu interior, visões distintas sobre um mesmo assunto. Não é? Tem sociedades muito mais voltadas para sua própria cultura, mas ainda assim com diversidade interna de posicionamentos. Por outro lado, há sim antropólogos indigenistas que me apontam que sim que há diferença de posições em relação ao que fazer em circunstâncias cotidianas dilemáticas. Apesar de uma cultura indígena se posicionar contrária ao aborto, uma menina pode querer abortar, o companheiro querer ajudar e o avô querer matá-la a pedrada se ela fizer isso. Por isso digo que não há essa ideia de sociedade "uniformatada", sem conflito, sem contradição, sem sofrimento. Como alguns antropólogos descobriram ou continuam a pensar que no outro todos pensam e agem sempre igual? Onde? Eu queria saber onde? É só ler um pouco de Psicologia, de Psicanálise para perceber que isso não nos leva a lugar nenhum. Então, esta é a minha briga com os antropólogos que reificam a noção de cultura. Especialmente aqueles 
que além de não serem feministas, são contra o feminismo. Entendeu? Geralmente são os mais voltados lá para uma cultura "uniformatada". Na verdade, a vida é um processo, é um processo contraditório. Subjetivamente nada é simples. Nesse sentido eu fico pensando que é importante, já que nós pensamos em termos abstratos, como pensar uma ressignificação de algum valor, ou de algum costume. O que fez o UNIFEM nesse sentido? Foi proposto que em vez de se fazer a excisão do clitóris, fosse montado um ritual que simulasse e simbolizasse o que o ato em si visava significar. Foi proposto uma substituição, quase que um simulacro do ritual que envolvia a excisão do clitóris, mas sem a excisão de fato. E algumas localidades aceitaram isso.

DRP: Como isso é interessante!

LZM: É bem interessante. Quer dizer, o UNIFEM propôs substituir o ritual. Buscou-se um diálogo com quem estava mais apto a mediar esse conflito. Outra coisa é pensar como se pode trabalhar com a questão. No meu ponto de vista alguns costumes da diversidade cultural que realmente implicam em, controlar, agredir e torturar mulheres, não são possíveis de se respeitar por princípio. Há que refletir. Não tem como respeitar um ritual de sacrifício das mulheres, em local nenhum, por exemplo. "Ah, mas foi sempre assim, temos que respeitar”. Não temos que respeitar! Temos que dialogar. Não estamos num outro mundo. Há sociedades indígenas originárias bastante segmentadas na sua história, quando havia um controle de uma elite. Não estamos mais nesse momento, então não dá para defender em nome da diversidade cultural manter esse ritual de sacrifício, Então, é possível defender a questão dos direitos humanos à la Conferência de 1993, dizendo que no que for contrário às mulheres em princípio ficamos com os direitos das mulheres desde que algumas ou todas estejam assim se posicionando. Mas é preciso produzir algo que equacione esse conflito. Faço um parêntesis. Não se pode também imaginar que nas sociedades modernas os estilos de vida das mulheres sejam uniformes. O Japão, a nossos olhos se apresenta como uma forma distinta e peculiar de combinar estilos de vida tradicionais e modernos, mas continua a diversidade de formas de combinação. Aliás eu vi um 
noticiário muito interessante sobre o Japão de como a modernidade das mulheres lá é variada. Tem estilos de vida de mulheres mais modernos do que nós, no Japão, e também os mais conservadores. Termino o parêntesis para dizer que considero impossível uma sociedade se tornar uniformidade inequívoca. Temos que abstratamente pensar como uma tradição pode se manter desde que ela não imponha um sequestro dos direitos das mulheres. Deste ponto de vista, penso que os antropólogos têm que ter óculos, binóculos ou simplesmente seus olhos mais simples atentos. Olhares e perspectivas que não vejam as sociedades cristalizadas como se entidades fossem, como se fossem valores culturais inertes e uniformes, mas sim que vejam relações sociais em socialidades em movimento, onde se relacionam pessoas, onde circulam valores, humanos e não humanos. Todas as culturas se movem. Ou seja, não podemos entrar em uma armadilha de pensar que o "selvagem" não tem nada a ver conosco. Não tem conflito, não tem sofrimento. Só tem disciplina. Eu vejo isso como uma conformidade absoluta; e não é isso! Não é só a Antropologia feminista que rompe com a armadilha de pensar o selvagem como um outro reificado. Para se trabalhar com gênero e diversidade cultural é preciso trabalhar com o que eu disse no começo: compartilhar não significa ter as mesmas posições, emoções, desejos, narrativas entre os sujeitos sociais. Existem poderes diferenciados, quando compartilhamos valores. Então, se podemos entender que as posições sociais são diferenciadas, que a perspectiva é situada; então é possível incluir o feminismo nesse olhar. O feminismo negro insiste mais ainda na metodologia interseccional; a posição situada não só de gênero, mas ao mesmo tempo gênero e raça, a intersecção gênero e raça. Do meu ponto de vista: gênero, raça e classe. Isso nos permite pensar muito mais a alteridade. Então, é olhar, a partir da nossa posição, as posições dos outros e tentar construir uma configuração das relações sociais. Assim, eu entendo que ser contrária à oposição dicotômica, simplista, entre sociedade moderna e sociedade tradicional, é fundamental. Se cortamos essa relação dicotômica como se um fosse a imagem negativa do outro, é possível perceber a existência de conflitos nos dois polos. Se conseguimos observar posições diferenciadas, podemos também observar que o compartilhamento dos valores é 
completamente diferente lá e cá. Mas a dinâmica da interação entre as diferenças de posições dos sujeitos existe aqui e existe lá. Portanto, gênero existe aqui e gênero existe lá. Acho que esse é o ponto. Não podemos dizer que gênero só existe na sociedade ocidental. Se podemos olhar assim, afastamos a visão "uniformatada", a oposição dicotômica, e conseguimos ver a diversidade cultural como ela realmente é. A socialidade, aí eu uso um pouco a Strathern (mesmo quando ela diz que a socialidade na Melanésia não tem o individualismo que nós temos) é relacional. Strathern diz que a pessoa é um indivíduo, mas um indivíduo que se relaciona. Ela vai dizer que não tem quem levante o braço para você a não ser você mesmo. Ou seja, tem a individualidade, tem o gesto, tem a posição individual. Você é "divíduo" relacional, mas você não deixa de ser indivíduo. Isso não quer dizer que na Melanésia se viva o valor do individualismo "nosso", mas é sim uma percepção do indivíduo que age, que se relaciona. Não tem como não ser! Por isso que é importante não antagonizar formas relacionais interacionais. E outra coisa que eu sempre digo, teoricamente, é que não devemos estudar narrativas isoladamente, sob pena de reificarmos representações. Narrativas no seio e no jogo das relações sociais. Por isso faço a crítica da noção de sociedade reificada, de estrutura reificada e inerte, de representações reificadas. Sim há sistemas societários atravessados pelas diversidades culturais, mas 'sociedades/culturas' se constituem em espaços de socialidade relacional, portanto, se movimentam. Se olharmos a sociedade se movimentando como relações; e não como soma de indivíduos, ou como como narrativa de uma época em que todo mundo falou aquela mesma narrativa; aí eu vejo um caminho que se abre para uma Antropologia que acolhe e dialoga com o feminismo, uma Antropologia, que não implica em nenhuma contradição com o feminismo. É possível assim fazer uma Antropologia feminista, e mesmo uma Antropologia não feminista, com uma metodologia absolutamente próxima. Mas se insistirmos em afirmar que as culturas são totalmente diferenciadas, e saem andando mecanicamente, podemos então estar caminhando para fazer algo totalmente contrário, uma Antropologia antifeminista. Como eu digo: "robot". Você robotiza a sociedade. Aí não tem 
feminismo, não é? Não tem desigualdade social, não tem classe social, não tem raça, não tem nada mais. Eu acho impressionante como questões tão importantes para a Antropologia, como questões étnicas, podem vir a ser negligenciadas se imaginarmos um construto único da China como sociedade. Se pensarmos uma sociedade como um construto funcional ${ }^{20}$. A China, por exemplo, quantas etnias tem? A diferença existe, também, no interior dessa sociedade. Aqui, no Brasil, há sociedades indígenas que incorporam outras etnias. Como elas exteriorizam isso? Como é que nós podemos ter constructos robóticos? É muito robozinho. E eu discordo de pensarmos a sociedade como um robô, até como máquina como alguns autores, grandes autores chamam. Porque tem um certo funcionamento de engrenagem, mas nunca é aquilo que nós projetamos. Na sociedade relacional tem conflitos e as pessoas divergem. Então é outra coisa que não a máquina. A máquina está lá, se entrar numa guerra ela vai até o fim. Aqui não. A estrutura social vai te obrigando a fazer isto ou aquilo, mas vai estar sempre acontecendo outra coisa, sempre essa sociedade estará se movimentando. Não existe uma engrenagem única, porque há posições sociais diferentes, há produção de valores diferentes, há simbologias diferentes e agora temos o vírus também!

MFS: Pensando na nova geração de mulheres no Brasil atual, qual é a leitura que a senhora faz do movimento feminista (ou movimentos feministas) neste contexto mais recente, em relação ao movimento de mulheres e movimento feminista da sua geração?

LZM: Tem coisas novas. Mas se a gente pensar que vivemos os movimentos feministas nos anos 70, fomos também uma revolução nova. É claro que tinha coisas novas no movimento feminista dos anos 70, que não tinham nada a ver com os anos 20, 30 ou do século XIX. Mas tem alguma proposta sempre que já

20 Em Machado, Lia Zanotta, Inserção Política: incômodo ou marca da Antropologia. Gênero e Sexualidade, um caso particular? In Lima, Antonio Carlos [et. al.] A Antropologia e a esfera pública no Brasil. Perspectivas e Prospectivas sobre a ABA no seu 60 aniversário. Rio: E-Papers e ABA, 2018, analiso o pensamento de Eunice Durham sobre os efeitos da teoria funcionalista para a reificação da noção de totalidade social. Ver também Durham, Eunice Ribeiro. A pesquisa antropológica com populações urbanas: problemas e perspectivas. In: CARDOSO, Ruth (Org.). A aventura antropológica. Teoria e pesquisa. Rio de Janeiro: Paz e Terra, 1986. p. 17-39. 
estava colocada nos inícios do século XX e mesmo no XIX. O movimento feminista é sempre um recomeço. É interessante perceber que há uma certa variação de como as novas feministas do milênio se veem. Tem umas que talvez achem que estão descobrindo, pela primeira vez, o movimento feminista, outras sabem que teve movimento antes. Aí eu nem posso dizer muita coisa sem antes falar sobre os anos 70. Nos anos 70 o que pensávamos? Estávamos fazendo viver o movimento feminista no Brasil. Líamos o que estava acontecendo na França, nos EUA; e pequenos grupos apareciam para inserir aqui essa discussão. Eu acho que nós tínhamos absoluta certeza de que nós estávamos certas sobre o que queríamos. Ou seja, qual é a questão? Hoje eu fico pensando, o que será possível fazer na situação atual? Na pandemia do coronavírus o que dá para fazer? O que dá para fazer com o aumento da violência nesse momento de pandemia? O que é possível fazer contra esse crescimento do neoconservadorismo? Eu me sinto muito mais impotente hoje do que eu me sentia nos anos 70. Nos anos 70 tínhamos uma certeza de que um dia a ditadura ia acabar. Na pandemia a gente tem menos certeza, claro. E depois era um movimento muito maior, não era só o movimento feminista. Tínhamos a questão indígena se movimentando, a questão ambientalista se movimentando. Tudo mais ou menos ali, no final dos anos 70. Então a ideia de que a ditadura, que tanto nos reprimia, estava acabando e que nós íamos conseguir nos impulsionava. Esse é o ponto, o caminho certo. A ideia de progresso, a ideia de ser progressista ou de ser de esquerda, pela democracia, era como um grande chamado em que muitos outros iam juntos. Mais ou menos isso. Eu acho que essa é uma diferença. Mesmo assim, não era nada fácil, porque começamos com grupos pequenos. Um jornalzinho pequeno, em São Paulo, outro jornalzinho no Rio, um seminário aqui, outro seminário acolá21. Em Brasília nós éramos um grupo pequeno. Não fomos os primeiros, Rio e São Paulo foram os primeiros mais representativos. Outros também devem ter acontecido, mas a nossa relação, que a gente tinha mais conhecimento do que estava acontecendo era no Rio e

\footnotetext{
21 Seria importante consultar, para uma versão menos informal e mais analítica, Machado, Lia Zanotta. Feminismos Brasileiros nas Relações com o Estado. Cadernos Pagu, Vol..1,2016.
} 
São Paulo além do Chile, Paris e Estados Unidos. Eram as referências. Então era como se trouxéssemos a "boa nova" [risos]. Não sei porque tínhamos essa tal certeza, porque não era nada fácil, mas tínhamos alguns ganhos públicos que eram significativos, quando, por exemplo, conseguimos criar as delegacias da mulher. Foi alcançar uma visibilidade, não é? A primeira visibilidade na imprensa talvez tenha sido a questão de Doca Street ${ }^{22}$, quando do segundo julgamento, em que aconteceu uma mobilização da imprensa. O segundo julgamento dá uma virada em relação ao primeiro. A imprensa de alguma forma nos vê. Talvez antes, naquele SOS Corpo, mesmo não tendo muita vivência, a morte de mulheres da classe média acabou trazendo muito a percepção da questão da violência no Brasil, especialmente permitiu que o feminismo fosse visto no Brasil com bons olhos. Porque antes era visto pela imprensa como um pouco ridículo. Tinha vindo para o Brasil a feminista norteamericana Betty Friedan que não foi bem recebida pela imprensa e em 1968 havia sido noticiado o protesto organizado pelo Movimento de Liberação das Mulheres que propunha a queima dos sutiãs durante a realização do concurso Miss América. Isso foi posto como ridículo do ponto de vista da imprensa, do ponto de vista da cultura dominante. Então, quando as mortes de mulheres de classe média e alta começaram a ocorrer, não apenas os espancamentos, mas a violência de morte mesmo; aí tivemos uma certa visibilidade do movimento das mulheres. E acabou que os políticos acabaram nos seguindo um pouco e ouvindo nossas demandas. Começaram a perceber que as mulheres iriam votar neles ou não, dependendo de seu posicionamento. Enfim, as mulheres já estavam integradas no mundo do trabalho, mas com um gap muito grande do ponto de vista dos direitos. Então, o movimento feminista avançou. Mariza falava que em Campinas, no grupo que ela participava, haviam jornalistas, comunistas, vários partidos, tinha também mulheres negras. Não havia o feminismo negro, de forma alguma, mas isso não queria dizer que nós fossemos o feminismo americano, de mulheres

\footnotetext{
22 Em 30 de dezembro de 1976, Raul Fernando do Amaral Street (Doca Street), após uma discussão com sua namorada, Ângela Maria Fernandes Diniz, desferiu quatro tiros contra Ângela, três no rosto e um na nuca, deixando-a totalmente desfigurada. O motivo do crime foi a não aceitação do fim do relacionamento.
} 
brancas. No meu grupo também havia mulheres negras. Era um feminismo de esquerda.

MFS: A senhora está falando da Mariza Peirano?

LZM: Não, Mariza Corrêa que trabalhava com família, já falecida. A primeira antropóloga brasileira que trabalhou com homicídios de mulheres. Mariza Corrêa $^{23}$. Ela era jornalista, quando se integrou em grupo feminista. Depois se transformou em antropóloga, com um trabalho sobre homicídios de mulheres. Na verdade, chamaríamos hoje de feminicídios. O que eu estou dizendo, citando os relatos de Mariza, é que tínhamos em nossos grupos mulheres operárias, mulheres do Itamaraty, mulheres que trabalhavam no Serviço Social, mulheres que vinham de partidos políticos, que eram funcionárias administrativas; toda essa diversidade dentro do movimento. Foi um movimento que tinha elite, mas que não era só elite. Tinha elite, mas tinha mulheres de partidos de esquerda não autorizados que, quando o bipartidarismo acabou, saíram da ilegalidade. Em São Paulo também foi assim. Muitas mulheres eram professoras ou estudantes. Foi um movimento construído também dentro da academia. Mais ou menos isso. O feminismo não tem dificuldade de entrar na comunidade acadêmica, parte dele nasce dentro das universidades, mas também trazendo setores de fora do acadêmico. Havia também uma vinculação com os movimentos de mulheres que eram comunitários. Eram aquelas mulheres provenientes de comunidades que defendiam trabalhadoras de determinados bairros e que lutavam por água e eletricidade para os seus bairros. Então, havia o movimento de mulheres e o movimento feminista; e a movimentação foi crescendo. Estava lá posta a questão do aborto, a questão da violência, a questão da saúde, enfim, era uma militância que implicava num certo ativismo presencial. Não havia essa questão de redes de Internet. Se você queria falar alguma coisa tinha que ir para Taguatinga, para fazer um

${ }^{23}$ Ver Corrêa, Mariza. Do feminismo aos estudos de gênero no Brasil: um exemplo pessoal. Cadernos Pagu (16), Campinas-SP, Núcleo de Estudos de Gênero - Pagu/Unicamp, 2001, pp.13-30. E ver Corrêa, Mariza. Morte em família. Representações Jurídicas de Papéis Sexuais. Rio: Edit Graal, 1983. 
discurso. Estou dizendo aqui em Brasília. Tinha que ir para Ceilândia, para falar alguma coisa. Organizamos um Fórum de Mulheres do Distrito Federal. Feministas de São Paulo e Rio organizavam seminários regionais e nacionais. Assim começaram os encontros feministas. Primeiro eram pequenos, depois começaram ser enormes. Passaram a ser lugares de aglomeração, cada vez crescendo mais. Além disso, formamos núcleos de estudos nos anos 80, vários grupos de estudos da mulher. Começamos a inserção também nas políticas públicas, as feministas nós participávamos de Conselhos estaduais, Conselho distrital, da criação de delegacias especializadas de atenção à violência contra as mulheres. Enfim, o movimento feminista entrou, em alguma medida, na área pública de gestão. Era como uma representação. Nas universidades o movimento entrou com força, na imprensa tínhamos também uma certa entrada. Não que tivéssemos muita aceitação, mas a oposição também era menor. Claro que havia os que eram contra, mas não era uma oposição organizada. Eu acho que hoje o movimento feminista tem uma oposição organizada. Porque nós lutávamos contra o conservadorismo da sociedade, das pessoas, da gestão pública. Era como se, de alguma forma, estivéssemos esclarecendo as pessoas. Lutávamos pela possibilidade de se ter um lugar para a mulher. Tudo era possível. Nós não tínhamos antagonismos tão grandes. E, algumas vezes, nós conseguimos importantes conquistas. O Sistema Único de Saúde (SUS), por exemplo, foi criado pelos sanitaristas e pelas feministas, em grande parte, porque nós fazíamos reuniões sobre saúde. Agora em alguns espaços nós não entramos muito. Por exemplo, na política. Mulheres na política quase não tiveram entrada. Não conseguimos alterar muita coisa. Agora, quando o movimento feminista, a partir dos anos 2000, começa a lutar pela inserção na política dizendo claramente que a mulher só entra se conseguir paridade, ou uma cota, daí a resistência foi enorme. Por quê? Porque hoje a resistência ao feminismo é muito grande no Brasil. Na Argentina as feministas conseguiram cotas e quase conseguiram o aborto mais recentemente. Aqui a oposição cresceu muitíssimo. Nos governos Lula e Dilma ainda havia a ideia de todos e todas, o que deu uma visibilidade maior ao feminismo. Era uma promessa maior de responder ao movimento 
feminista, embora se olhássemos de trás para frente começou no Lula e depois foi parando. Uma vez me perguntaram se houve cooptação do movimento feminista pelos governos petistas. Eu respondi: “não, não houve, mas eles deram mais espaço ao movimento feminista, mais do que nos governos anteriores". Isso é fato, porque conseguimos avançar em várias coisas, legislação do Código Penal, a Lei Maria da Penha, nós conseguimos um monte de coisas. Mas, o que queríamos mais, pois era o mais difícil, não conseguimos, que era a questão da legalização do aborto. Eu acho que a virada desses movimentos conservadores, configurando uma oposição mais difícil para as feministas foi na proposta tripartite para a legislação que permitisse a interrupção da gravidez até as doze semanas em 2005. Para mim ali virou. Ali virou porque no Congresso perceberam que o governo executivo estava nos apoiando. Esse projeto parou porque o Congresso fez pressão para que o Executivo não desse mais espaço algum. Nesse momento a então Ministra Nilcéia Freire, que tinha nos defendido, disse: "agora fiquem vocês, porque nós não vamos poder fazer mais nada". Claro que, como disse antes, isso aconteceu em função do mensalão. Mas a partir dali o que o Congresso faz? Ele cria uma sequência de redes, de frentes parlamentares contra o aborto, a favor da vida, e da família. E vai consolidando e armando as três frentes: a frente agropecuária, a frente evangélica e a frente da bala ${ }^{24}$. Então elas tecem um circuito que é a favor da família e da propriedade, contra o aborto e contra o direito das mulheres. Então, a partir dali essa oposição, que nasce no Congresso, se fortalece. A frente evangélica, criada antes, em 2003, ainda era uma frente com pouca gente e que não tinha esse casamento com as outras frentes. Eles irão se unir depois. Ao fazer o enfrentamento contra o aborto, essa frente vai captando gente das outras frentes para trabalharem, também, contra o aborto e, com certeza, contra o feminismo. Então surge uma oposição enorme a partir de 2005. Antes, também é importante dizer, a década de 90 foi uma década de sucessivas reuniões internacionais que deram muito apoio a muitos movimentos. Nos anos 2000 começa a declinar a força das

\footnotetext{
${ }^{24}$ Ver Machado, Lia; Motta; Antonio e Facchini, Regina Quem tem medo dos antropólogos/ Praticas
} cientificas nos novos cenários políticos. Revista de Antropologia USP, v 61, p. 09-32, 2018. 
conferências sobre os direitos humanos (há uma diminuição das conferências intergovernamentais), e, ao mesmo tempo, a ascensão do neoconservadorismo passa a influir no crescimento do uso das redes sociais pelos antifeministas. Não é que são antiabortistas, eles são antifeministas mesmo. É um pouco nesse sentido que eu vejo que há, hoje, uma oposição muito maior. Uma blogueira feminista que escreve determinadas coisas hoje, tem não sei quantas pessoas falando contra. Talvez, antes, diziam os opositores do feminismo que o que defendíamos era uma coisa sem sentido, mas não havia alguém fazendo outra narrativa só para arrebentar a nossa. Havia menos discursos antagônicos e as narrativas contrárias eram menores e muito menos organizadas. Hoje o movimento feminista até tem atividades presenciais, como a marcha das vadias, por exemplo, mas os grupos, as ONGs, atuam mais nas redes. Há um crescimento das redes internacionais de ONGs, mas ONGs que nem sempre têm recursos. Umas têm recursos, outras não têm recurso algum. Nos anos 90 o movimento era muito mais integrado com o Estado, que defendia e levava em suas redes internacionais o que as ONGs diziam e demandavam. Eu penso que há algumas coisas interessantes nesse novo feminismo, que está agora também nas redes virtuais, ele é extremamente criativo e também é bastante variado. Há uma força muito grande do feminismo negro, por exemplo. Dos movimentos antirracistas que eu vejo que são muito consistentes, muito fortes em termos de ONGs, movimentos negros como o Geledés ${ }^{25}$ e o Criola ${ }^{26}$, há uma forte produção de acadêmicas feministas negras. Há uma entrada muito grande, digamos, da defesa dos direitos feministas, através dos movimentos das mulheres negras que colocam claramente a impossibilidade de se fazer só um movimento feminista, mas sim de um movimento feminista antirracista no Brasil. Eu acho que é isso mesmo. Nós nunca fomos um movimento, lá nos anos 70, nem branco, nem só elitista. Sempre fomos entremeados, vinculados a membros de movimentos de classes populares. Agora às vezes eu ainda escuto: "mas esse movimento de vocês era de mulheres brancas”. Espera aí, nós viemos de uma ditadura, com

\footnotetext{
$25 \mathrm{https} / / /$ www.geledes.org.br/

${ }^{26}$ https://criola.org.br/
} 
toda essa variedade de mulheres, lutando pela democracia, pelo Sistema Único de Saúde, por políticas de enfrentamento à violência. Movimento de mulher branca? Claro que não. Mas faltava a explicitação da pauta antirracista e da proposta de analise intersecional de gênero e raça. Agora tem uma novidade, há uma colocação, uma exteriorização da pauta antirracista. Já faz tempo que o movimento feminista negro brasileiro, influenciado fortemente pelas feministas negras norte-americanas, encaminham também as demandas e se organizam fortemente. O movimento feminista negro cresceu e estimulou a que todos os movimentos feministas brasileiros se declarem e se organizem como feminismo antirracista, que eu penso ser fundamental e que, dada a forte oposição neoconservadora precisa cada vez mais fazer alianças. Que as mulheres negras falem e que as mulheres brancas reconheçam que temos que combater o racismo. Realmente, nesse tema aqui estamos mal. E os movimentos feministas antirracistas são a favor da democracia e criticam o fato de jovens negros homens morrerem nas mãos dos policiais. Enfim, eu vejo que aí está presente essa característica, que era também fundamental nos anos 70, que é toda a movimentação feminista brasileira ser também uma movimentação pró-democracia. É muito claro que o feminismo sempre foi pró-democracia e continua como tal. $\mathrm{O}$ número de blogueiras feministas e de blogueiras feministas antirracistas está crescendo assim como feministas negras estão se incorporando às universidades para em mestrados e doutorados produzirem pesquisas. Estão se constituindo e crescendo em número de autoras de saberes acadêmicos feministas também. Um exemplo disso é o crescimento das revistas que tratam do tema feminismo, gênero e raça. Como vocês haviam me perguntado, sobre a questão editorial, façam novamente a pergunta, por favor.

MFS: De certa forma a senhora até respondeu. Nós pensamos no mercado editorial, até fora do âmbito acadêmico, em como ele vem crescendo, sobretudo, com traduções de trabalhos já antigos ou relançamentos, por exemplo, da Simone de Beauvoir ou autoras negras, do feminismo negro, que estavam fora do mercado (Angela Davis, Patricia Hill Collins, bell hooks, entre outras). Antes nós tínhamos, sem contar as revistas acadêmicas 
específicas que tratam das questões feministas e das mulheres, por exemplo, a Rosa dos Tempos, que era uma editora quase que isolada neste mercado. Nesse sentido, a questão sobre o mercado editorial é mais para ouvirmos um pouco como a senhora tem acompanhado este momento de crescimento para as produções das mulheres feministas e o que a senhora tem percebido de mais positivo no crescimento deste mercado editorial?

LZM: A primeira coisa, eu penso que esse crescimento editorial não teria lugar se não tivesse tido a expansão dos movimentos feministas e dos movimentos antirracistas. Então, quando entramos no site do Criola, ou no site do Geledés, é possível encontrar material de leitura farto, não só de feministas acadêmicas, negras ou não, mas também de romances. Romances feitos por feministas, romances feitos por feministas negras, brasileiras, americanas, traduzidos ou não. Então, eu vejo que o fato de termos tido uma expansão das ONGs feministas antirracistas, repercutiu na expansão de revistas acadêmicas, sobre feminismo, sobre LGBTs, sobre travestimentos, sobre racismo, etc. Essa expansão das editoras, eu vejo que aconteceu depois da expansão dos artigos nas revistas acadêmicas e também da inserção, na Internet, dos trabalhos das ONGs, como Geledés e Criola, nos seus sites virtuais e também do CFEMEA ${ }^{27}$, que instituiu no âmbito virtual a universidade feminista ${ }^{28}$. Esses sites são importantes porque buscam autoras negras, que, às vezes, não recebem a visibilidade merecida. Chimamanda Ngozi Adichie, por exemplo, uma feminista nigeriana com um livro interessantíssimo, eu tive acesso assim. Então temos sim o mercado editorial brasileiro traduzindo isso ou aquilo, e publicando autoras brasileiras, mas também temos uma expansão da leitura feminista como um todo. Isso não só aqui, mas em outros países também como EUA e Inglaterra. Quando eu fui para os EUA, em Nova Iorque, no ano de 2009, vi várias revistas. A quantidade de produção que temos aqui não chega aos pés do que é produzido lá, nem em termos de produção das ciências sociais em gênero nem de literatura sobre gênero, feminismo e diversidade sexual. As literaturas e a

27 https://www.cfemea.org.br Centro Feminista de Estudos e Assessoria.

28 https://feminismo.org.br/ Universidade Feminista Livre. 
produção feminista americanas e inglesas são potentes. Há muita produção indiana sobre a questão feminista. Então, eu percebo que houve uma expansão do feminismo e do antirracismo, que começa nos anos 90, e que está chegando nas editoras agora. Quem publica na área de gênero hoje no Brasil? Boitempo, Vozes, Rosa dos Tempos, Editora Perspectiva continuam.; e surgem e se consolidam as novas editoras como Bazar do Tempo, Elefante, Boitatá, Cobogó, Malê, Nós, mulheres da periferia ${ }^{29}$. E temos também as editoras tradicionais estrangeiras, inglesas e americanas, como a Routledge e a Sage. Temos, portanto, uma expansão editorial que responde muito a uma produção da literatura, mas especialmente a produção dos movimentos feministas e antirracistas na academia. Essa expansão de editoras voltadas a feminismo e antirracismo e literatura feminista negra ou não é muito importante porque às vezes são a partir das pequenas revistas acadêmicas que começam a colocar essa questão e aí as editoras menores e maiores respondem. E olha que responder como editora, no Brasil, não é nada fácil. Porque não podemos ignorar o quão difícil é manter uma editora no momento atual. Muitas vezes elas são compradas e depois fechadas. Talvez o futuro seja cada vez mais do e-book, porque realmente nós estamos num momento em que a Internet é mais fácil. Ainda não chega a todo e qualquer lugar, mas ela chega bem a quem lê. Para termos mais pessoas que leem nós precisamos fazer com que a Internet chegue mais adiante, a inclusão da leitura também via Internet. Minha casa tem livros até no teto, tem na outra sala, no quarto. Meu marido também é professor, então temos muitos livros. Isso não existe mais, porque não precisa. É sempre bom ter o livro, o cheirinho do livro, mas quando eu olho tudo que eu acumulei acho que tem um certo exagero. Porque não havia outra forma de manter o que se queria ler se não fosse fisicamente. Agora temos as duas formas. E eu percebo que as editoras estão sofrendo um pouco com isso, porque fazendo a editoração de um livro e vendendo em e-book ganha-se quase nada, perto do que se ganhava na produção impressa. Paras as editoras menores isso é ruim. Quando vocês me perguntaram sobre as editoras, outra coisa que eu também penso é que há algo de novo, que é

\footnotetext{
${ }^{29} \mathrm{http} / / /$ nosmulheresdaperiferia.com.br/noticias/editora-feminista
} 
justamente o fato dessa editoração de livros, coletâneas ter advindo muito mais do efeito do crescimento das revistas acadêmicas que passaram a integrar mais as pessoas em torno da questão de gênero. Eu acho que houve um feito - dentro da área de Ciências Sociais, Sociologia, Antropologia, História, Literatura - muito grande. Tem muita gente pesquisando gênero, mesmo que o tema gênero seja pesquisado junto a outros temas. Acho importantíssimo, não apenas pesquisar gênero, mas incluir gênero no que se pesquisa. Isso também possibilitou o aparecimento dessas novas editoras, sem que o seu trabalho esteja sendo fácil. Neste momento penso que estamos, talvez, numa encruzilhada. Vejo com bons olhos esse crescimento editorial; vejo como uma resposta da expansão e diversificação do próprio movimento feminista. Agora, em compensação, é preciso muito cuidado com tudo que é publicado e que antagoniza os feminismos. Nós temos que pensar no neopentecostalismo que também produz e que tem como alvo muito da produção de gênero, diversidade sexual e feminismo. Qual é a produção de vídeos? Qual é a produção de livros, inclusive de baixo custo, dentro de determinadas igrejas evangélicas? É baixíssimo o custo de produção de material formativo de muitas das igrejas e facílima a divulgação. Mesmo os programas de televisão que tratam do tema. Eu sou a favor da liberdade religiosa e respeito muitíssimo religiões e religiosidades, mas sou muito preocupada com o moralismo implícito, impositivo, contrário aos direitos das mulheres que está inserido em vários programas religiosos de TV e rádio. Há igrejas e seitas religiosas evangélicas que admitem homossexuais, mas a maioria das grandes igrejas continua discriminando homossexuais e colocando a mulher, entre aspas, "no seu lugar". "Fiquem em casa. Ajudem o seu marido". Eu ouvi de um pastor a seguinte questão: "Quem é que pode dirigir o carro? Duas pessoas podem dirigir um carro? Não, não podem. Só uma pode. Então, você como mulher só pode ser co-piloto de seu marido, que é o piloto. Pronto". Essa é uma questão relevante, o "antifeminismo" cresce também em torno de muita formação discriminatória disciplinadora. Eu como antropóloga acho importantíssima a questão da religião ou das religiões, no plural, mas diante da questão dos direitos, muitas vezes a religião é um 
confronto aos direitos das mulheres, aos direitos dos homossexuais. Neste sentido, temos uma competição muito desigual em matéria de produção editorial. A produção de vídeos, a produção de artigos, também são fantásticas nas redes sociais e na Internet e muita religiões já assimilaram isso. Então nós temos que ver que também há esse contraponto. Uma produção que é desigual e que muitas vezes se contrapõe à diversidade sexual e à igualdade de homens e mulheres. Uma produção de programas de Tv e de rádio e de sites na Internet que se alinham com a crescente movimentação neoconservadora ${ }^{30}$.

DRP: Para terminar, professora, a senhora pode falar um pouco sobre suas experiências extra-acadêmicas? Por exemplo, como conselheira no Conselho Nacional de Direitos das Mulheres e, também, como membro de Comitê de Monitoramento da Secretaria de Políticas para as Mulheres (2005 a 2008). Nós demos esses dois exemplos, mas fique à vontade para falar das suas experiências para além da academia.

LZM: Olha, rapidamente para não repetir alguma coisa que eu já contei. Eu comecei num movimento feminista que chamava Brasília Mulher, que tinha intelectuais, tinha diplomatas, tinha operárias, tinha defensoras públicas, etc. Um grupo de cerca de 40 pessoas. A gente fazia palestras e dava entrevistas para jornais. Eu fui para Taguatinga, Ceilândia, e outros lugares para falar de feminismo. Ao mesmo tempo comecei a trabalhar a questão de gênero academicamente. Então, tem um pouco esse caminho em que a questão de gênero entra nos meus estudos - de família, de identidade, de individualismo e simbologia -, mas tem outro lado, um interesse meu, que eu estou respondendo também a uma militância. Então, eu me considero uma intelectual que não vê oposição entre esses dois caminhos. São duas coisas diferentes. Eu trabalho como uma intelectual e sou também uma militante.

\footnotetext{
30 Ver Dossier que organizamos em 2018, Lia Zanotta Machado, Antonio Motta e Regina Facchini na Revista de Antropologia USP: Quem tem medo dos antropólogos? E ver Dossier que estamos organizando Lia Zanotta Machado e Antonio Motta: "Anthropology in times of intolerance: challenges facing neoconservatism" e em parte já com artigos publicados na Revista Vibrant. Vol. 16 e Vol. 17, 2019.
} 
Elas não são opostas e nenhuma se reduz à outra. $\mathrm{O}$ que eu faço como uma intelectual pesquisadora não significa que minha pesquisa seja militante. Eu não faço isso. Eu faço pesquisa a partir de todas as normas científicas, mas a minha perspectiva de olhar é voltada para minha posição política de que eu quero igualdade e quero direitos para as mulheres. Suposto. Voltando a minha trajetória, eu, primeiro, entrei nesse grupo chamado Brasília Mulher. Mais tarde, esse grupo se dividiu. Uma parte formou uma ONG chamada CFEMEA $^{31}$, que continua existindo até agora; e outra parte continuou no Núcleo de Estudo e Pesquisa sobre Mulher (NEPeM), que Mireya Suarez construiu junto comigo e outras três colegas, dentro da UnB. Um pouco mais tarde, quando houve divisão de grupos dentro do CFEMEA; aí parte do NEPeM, juntamente com parte do CFEMEA, construímos a AGENDE (Ação em Gênero, Cidadania e Desenvolvimento), uma organização não governamental (ONG). Na Agende tínhamos entre os membros, professoras que participavam, não com trabalhos executivos, mas fazendo alguns projetos ou simplesmente participando de colegiados e conselhos, etc. Por participar da Agende, imediatamente eu também entrei, no decorrer dos anos 90, para a Rede Nacional Feminista de Saúde e Direitos Sexuais e Reprodutivos criada em 1991. Essa grande rede depois foi seguida por um processo de criação de várias outras redes: Rede das Mulheres Negras, Rede de Articulação das Mulheres Brasileiras. Várias grandes redes feministas foram criadas nos anos 90. Essas várias redes passaram a compor o Conselho Nacional de Direito das Mulheres. Na época do Lula, o Conselho mudou seu estatuto. Antes havia o Conselho Nacional, mas ele era composto por pessoas escolhidas por indicação do governo. Ao ser criado o Conselho em 1985, eram 17 integrantes todas indicadas pela Presidência da República, das quais um terço deveria ser escolhido dentre pessoas indicadas por movimentos de mulheres. Eram indicadas algumas mulheres pelos movimentos feministas e pelos movimentos de mulheres, e por centrais sindicais, mas a escolha dos nomes era política. Quando Lula chega, ele resolve que quem indica as representantes da sociedade civil do Conselho são as próprias redes e setores

\footnotetext{
${ }^{31}$ Centro Feminista de Estudos e Assessoria.
} 
de mulheres nas centrais sindicais ${ }^{32}$. Então, é nesse momento que eu entro como representante feminista da Rede Nacional Feminista de Saúde e Direitos Sexuais em 2005. Eu entro primeiro como vice e depois como titular. Fico duas gestões lá. É bastante demorada minha permanência dentro do Conselho Nacional de Direitos da Mulher. Isso foi, para mim, muito importante. Enquanto isso, as organizações não governamentais, se organizaram em consórcio e em parceria com a Secretaria de Políticas para as Mulheres elaboravam a proposta de Lei Maria da Penha. Faziam parte desse consórcio: Ações em Gênero, Cidadania e Desenvolvimento (AGENDE); Advocacia Cidadã pelos Direitos Humanos (ADVOCACI); Cidadania, Estudo, Pesquisa, Informação e Ação (CEPIA); Centro Feminista de Estudos e Assessoria (CFEMEA); Comitê Latino-Americano e do Caribe para a Defesa dos Direitos da Mulher (CLADEM); e a Assessoria Jurídica e Estudos de Gênero (THEMIS) Então, eu participei da construção dessa lei, como participante da Agende e como membro do Conselho. Na hora em que o projeto de lei estava sendo discutido pelo consórcio eu já estava no Conselho. Como seriam os juizados, se eles seriam juizados criminais, juizados civis, ou juizados de pequenas causas. Foi uma tensa e forte discussão. O consórcio fez uma proposta, e a ministra pela Secretaria de Políticas para as Mulheres fez uma outra e aí o debate passou para as mãos da Deputada Federal Jandira Feghali que levou as dúvidas para diversas regiões do país. Continuamos discutindo, enquanto Conselho, como é que seria essa lei e o consórcio também discutindo. Como se observa, eu estou em diferentes posições dentro da discussão sobre a Lei Maria da Penha que finalmente foi promulgada em 2006. Essa é uma das atividades extra-acadêmicas que eu fiz. A outra foi minha atuação em diversas frentes como conselheira e como representante do Conselho junto a várias instituições. Eu tinha um papel importante porque como eu era de Brasília, então me chamavam mais facilmente. Para, por exemplo, ir ao Ministério do Trabalho discutir a questão da lei das empregadas domésticas, que afinal foi aprovada mais tarde. Eu participei da

\footnotetext{
32 Para maiores detalhes ver Machado, Lia Zanotta. Feminismos Brasileiros nas relações com o Estado. Cadernos Pagu. Vol..1, 2016 e Pimenta, Fabricia. O Conselho Nacional de Direitos da Mulher (19852005) UnB, 2010.
} 
discussão naquele momento, também como conselheira. Era preciso que o Conselho não ficasse só cuidando das questões das mulheres, de forma separada, mas que os outros ministérios estivessem conectados conosco. Nesse sentido, eu participei do monitoramento das demais áreas com relação às mulheres. Foi criada um Comitê de Monitoramento. Talvez não só pelo fato de eu morar aqui em Brasília, mas também por ter certo tato político, alguma habilidade política, eu participei muito da criação dessas novas formas de monitorar a questão de gênero, de fazer políticas públicas de gênero, de participar da construção das Conferências Nacionais dos Direitos das Mulheres, debates etc. Então, minha participação também foi muito nessa linha. Na questão do aborto eu tenho um papel bastante importante, antes mesmo da primeira conferência, na qualidade de participante da Rede Feminista e não na qualidade de membro do Conselho. A proposta para a legalização do aborto não foi levada a Primeira Conferência Nacional dos Direitos das Mulheres nem pelo Conselho nem pela Secretaria de Políticas para as Mulheres. A Rede Feminista integrava a movimentação pelas Jornadas para a Legalização do Aborto. Fizemos uma discussão inicial que congregou várias organizações não governamentais pró legalização do aborto. O projeto era levar, para a I Conferência, uma proposta de legalização do aborto. Isso foi proposta do movimento, contra o desejo, naquele momento, do Conselho ou da Secretaria (SPM). Mas a conferência tinha formato democrático. Nós do movimento conseguimos que nossa proposta ganhasse por votos das delegadas nas Conferências Estaduais e na Nacional, Uma vez aprovada a proposta, teria que integrar o I Plano Nacional de Políticas Publicas para as Mulheres. A regra era essa. Foi nesse momento que enfrentamos as maiores dificuldades. Mesmo antes do "mensalão" já estava tudo difícil, para que o governo aceitasse a introdução pela ministra no Plano Nacional da proposta de elaboração e envio ao legislativo de projeto de lei pelo Executivo para a legalização do aborto. Aí a ministra que tinha uma habilidade política muito grande falou: "vamos fazer o seguinte: em vez de ser um projeto do executivo, vai ser um projeto de uma comissão tripartite”. Um terço do Governo Federal, seis representantes. Outros seis representantes do 
Parlamento, três da Câmara dos deputados, três do Senado. E outras seis da sociedade civil, que era representada pelo Conselho. Dos seis nomes que deveriam representar a sociedade civil, a Ministra propôs que fossem quatro destinados a conselheiras representantes da sociedade civil no Conselho Nacional de Direitos das Mulheres e dois de sociedades civis exteriores ao Conselho. Todos os nomes a serem eleitos pelas conselheiras. Para as associações exteriores ao Conselho, foram eleitas a SBPC (Sociedade Brasileira para o Progresso da Ciência) e a FEBRASGO (Federação Brasileira das Associações de Ginecologia e Obstetrícia). Aí foi feita a eleição de quatro mulheres do Conselho, das quais eleitas uma delas fui eu. Então, eu participei da comissão tripartite pela legalização do aborto, em nome do Conselho, representando o Conselho. Isso foi para mim muito relevante. Além da questão do aborto, como disse antes, o monitoramento das políticas públicas de gênero também foi atividade bastante enriquecedora. Discutíamos com todos os ministérios. Cada representante da Comissão de Monitoramento tentava organizar quais eram as suas atividades e como se articulavam com todos os outros ministérios. Alguns ministérios eram mais afins à nossa causa, como o Ministério da Saúde, ou o Ministério do Desenvolvimento Agrário; e tinha outros que não. Era, na verdade, meio ficcional a presença de alguns deles porque a pessoa que representava o ministério, muitas vezes não tinha condições de decisão, de impor um programa. De qualquer forma, foi a primeira vez que se tentou fazer um planejamento sobre a questão de gênero que não fosse só exclusivamente da Secretaria de Políticas para as Mulheres. Então, isso foi uma coisa, assim, de dimensão inovadora. Agora não temos nada disso, não é?

DRP: Agora estamos vivendo tempos assustadores professora.

LZM: Então o monitoramento estava começando. Nós conseguimos, por exemplo, visibilizar melhor as políticas para as mulheres junto ao Ministério do Desenvolvimento Agrário. Havia programas, como destinar o registro da propriedade de terras para as mulheres e não para os homens. Agora, alguns ministérios mal apareciam. Pelo menos tentávamos e também tínhamos 
alguns dados que funcionavam também para eles. Então foi um trabalho de negociação e de modelagem. Quais são as metas? Quais são os objetivos? Fazíamos planos. No final do meu mandato como membro do comitê de monitoramento e de conselheira, a grande discussão, já quando estava saindo, foi quando o II Plano Nacional de Políticas Públicas para as Mulheres, não incorporou o objetivo de elaborar projeto de lei pela legalização do aborto novamente aprovado na II Conferência Nacional. Foi nesse momento nosso desentendimento com a ministra que sempre admirei. Sabedora de todas as dificuldades políticas da realização efetiva da proposta, ainda assim eu queria que constasse no Plano, mesmo que simbolicamente...Eu tive a coragem de dizer: "olha, a segunda conferência, de novo, aprovou e agora vai ter que colocar no Plano". E ela disse: "ah, não, não vai dar". E ela não queria. E provavelmente não podia.

DRP: Ela não quis pagar o preço político.

LZM: Não queria e nem podia. Ela não ia conseguir, entendeu? Mas quem sabe poderia estar tentando. Talvez até achasse que iria conseguir. Mas não iria! É que tinha crescido muito a posição antiaborto, muito. Tinha crescido e agora está até maior, pois não se fala mais disso. A oposição está muito maior porque não estamos mais falando de aborto no Brasil. Em alguma medida conseguiram, de alguma forma, nos calar. Agora começam a falar contra o aborto legal nos hospitais. Isso está dentro do Código Penal desde 1940. Enfim, vocês vejam o quanto o tema está absolutamente espinhoso. Mas o que mais? O que vocês queriam?

DRP: Acho que agora é só professora. Não sei, se a senhora quiser nos falar de mais alguma atividade extra-acadêmica, fique à vontade.

LZM: Eu quero dizer um assunto que me veio agora, voltando um pouco à questão acadêmica. Nos anos 80, meu departamento de Antropologia, e vários outros departamentos, criaram várias disciplinas associadas ao gênero. Antropologia das Mulheres e depois Antropologia de Gênero foram criadas. 
Reuniões da ANPOCS ${ }^{33}$ criaram grupos de trabalho sobre Gênero e Família, Gênero e Trabalho, Gênero e Política, etc. Naquela época, tínhamos especialmente, pesquisadoras e pesquisadores de gênero. A partir de um determinado momento, final dos anos 90, e durante os anos 2000, o interessante é que aumentou, dentro da universidade, o número de estudantes que queriam fazer estas disciplinas. Além disso, também apareceu uma novidade. Tinha muita gente que não se dizia pesquisadora de gênero, que não estudava gênero, mas que se dizia feminista. Muita gente, em sala de aula falando ser feminista. Muito interessante isso. Depois muitas feministas negras, também. Com certeza o sistema de quotas raciais fez a diferença na inclusão de estudantes negras/os e pardas/os. Levando em consideração minha trajetória, eu acho relevante notar como agregamos muitas feministas. Não sei se as outras universidades viveram isso. De repente, tinham feministas na minha sala; maravilhosas!

DRP: Que bom, não é? Eu também percebo isso professora. Eu oriento hoje, no mestrado do Direito, alunos que estudam Criminologia Feminista e Criminologia Queer. Isso é absolutamente novo, até para mim. Eu aprendo junto com eles. Isso é interessantíssimo.

LZM: Então, aqui no Direito da Universidade de Brasília (UnB) eu tenho orientado várias alunas. Inclusive as pesquisas e orientações que estou fazendo agora são sobre a Lei Maria da Penha. Vocês não me perguntaram, mas eu vou dizer, estou pesquisando agora Juizados de violência contra a mulher. Eu inclusive já publiquei alguns resultados em coletâneas ${ }^{34}$. Publiquei um texto agora sobre feminicídio ${ }^{35}$. Nesse sentido estou entrando muito na área de pensar o que acontece com a questão da violência no campo jurídico. Sobre a Lei Maria da Penha e sobre o feminicídio. É com o que estou

\footnotetext{
33 Associação Nacional de Pesquisa e Pós-Graduação em Ciências Sociais (ANPOCS).

${ }^{34}$ Machado, Lia Zanotta Violência contra as Mulheres: Diálogos entre Feminismo e Ciência Social. In Dias, Alfrancio et all (orgs) A Transversalidade de Gênero na produção do Conhecimento e nas Políticas Públicas. Aracaju: Edit IFS, 2017. Ver também Machado, Lia Zanotta. Violência Baseada no Gênero e a Lei Maria da Penha. In Barbosa,Theresa [et al.] (orgs) A Mulher e a Justiça. A violência doméstica sob a ótica dos Direitos Humanos. Brasilia: AMAGIS, 2016.

35 Machado, Lia Zanotta. Féminisme, Nommer pour Exister. Brésil(s). Vol. 16, Dossier Genre et justice, 2019 .
} 
trabalhando agora. E o que eu vi na área do Direito é que não tinha praticamente ninguém que trabalhava com gênero. Uma ou duas pessoas apenas. Agora que tem mais. Eu me lembro de um estudante que foi fazer pós-graduação em Antropologia, vindo do Direito - isso nos anos 90, não agora. Eu dei aula sobre violência de gênero e violência sexual. Ele era todo sério e disse assim: "professora posso entregar o trabalho um mês mais tarde?". Eu falei assim: "por quê? explique”. Ele respondeu: "é o seguinte: a senhora me 'desensinou' tudo o que eu sabia sobre estupro. Eu tenho que rever. Eu quero fazer uma coisa boa porque eu acho que estou com a cabeça já mudada”. Eu achei isso muito interessante. Hoje já existe, na área de Direito, muito mais gente que é feminista, como professor, inclusive. Então, está mudando alguma coisa. É isso que eu queria dizer, este lado para o qual minhas pesquisas me levaram, escrever sobre práticas jurídicas; o que estou fazendo já há um bom tempo. Agora estou tendo um contato maior com o Direito, que era uma área em que o feminismo não tinha nada a ver. Era antifeminista total. Bom, então é isso.

MFS: Foi excelente professora! Uma maravilha! Eu agradeço muito.

DRP: Foi excepcional! Estou felicíssima também. Muito obrigada. Foi muita generosidade ter essa conversa conosco. Para nós, foi um aprendizado enorme.

LZM: Ai que bom! Muito obrigada.

DRP: Nós que agradecemos essa entrevista maravilhosa. 